Portland State University

PDXScholar

$5-1-1970$

\title{
A Follow-up study of families with children labeled retarded
}

Connie Finley

Portland State University

Kay Jernigan

Bonnie Hogan

Effrosini Rotous

Daryle Steffen

Follow this and additional works at: https://pdxscholar.library.pdx.edu/open_access_etds Let us know how access to this document benefits you.

\section{Recommended Citation}

Finley, Connie; Jernigan, Kay; Hogan, Bonnie; Rotous, Effrosini; and Steffen, Daryle, "A Follow-up study of families with children labeled retarded" (1970). Dissertations and Theses. Paper 671.

https://doi.org/10.15760/etd.671

This Thesis is brought to you for free and open access. It has been accepted for inclusion in Dissertations and Theses by an authorized administrator of PDXScholar. Please contact us if we can make this document more accessible: pdxscholar@pdx.edu. 
AN ABSTRACT OF THE THESIS OF Connie Finley, Kay Jernigan, Effrosini Rotous, Bonnie Hogan and Daryle Steffen for the Master of Social Work presented May 15, 1970.

Title: A Follow-up Study of Families with Children Labeled Retarded APPROVED BY MEMBERS OF THE THESIS COMMITTEE:

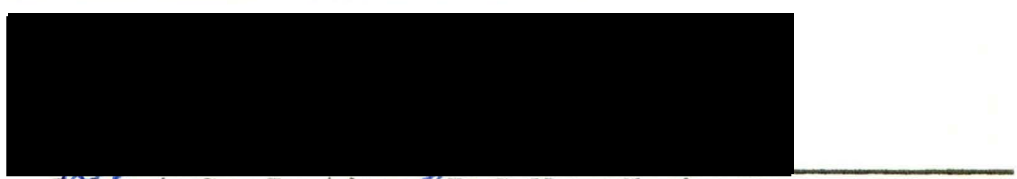

Robert S. Justice/, D.S.W., Chairman Associate Professpr

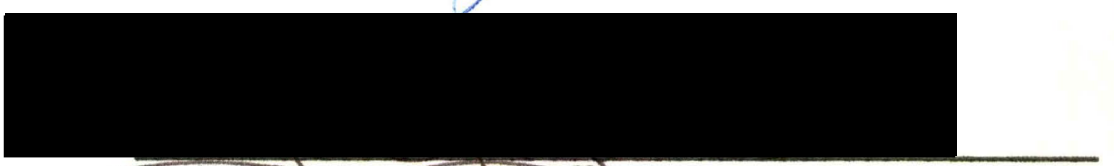

Jack Heglene,, A.C.S.W. Assistant Professor

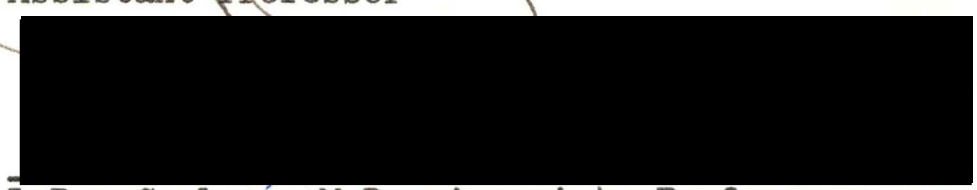

LeRoy Carlson, M.D., Associate Professor

University of Oregon Medical SchoolCrippled Children's Division

The research problem undertaken was to study how effective the University of Oregon Medical School-Crippled Children's Division Clinic is by determining how well patients followed through on Clinic recommendations. Three research hypotheses were posed for testing.

(1) There is a difference between income and the following of Clinic recommendations.

(2) There is a difference between educational levels of fathers and mothers and the following of Clinic recommendations.

(3) There is a difference in the level of I.Q. of patients and the following of $\mathrm{Clinic}$ recommendations. 
A random sample of 100 cases was selected from the patients who had been through the Clinic prior to January, 1968. Case records were abstracted from the files of the University of Oregon Medical SchoolCrippled Children's Division, prior to personal interviews in the homes with the families using a standard questionnaire. The $\mathrm{x}^{2}$ was used in testing the hypotheses and the findings resulted in no statistical difference between the three variables and the criteria of following recommendations. Therefore the null hypotheses were accepted. 
A FOIIOW-UP STUDY OR FAMTIES MTH

CHILDRFI IABESED REIARDED

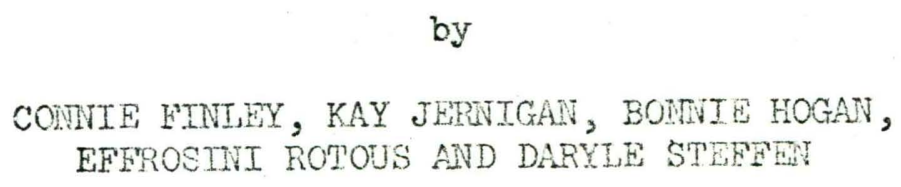

EFEROSINI ROTOUS AND DARYLE STEREEN

\begin{abstract}
A thesis submitted in partial fulfillment of the requirements for the degree of
\end{abstract}

MPSTER OF SOCIAJ, WORK

Portland State Universituy

1970

\title{
PORTLAND STRTE GWWERTIY LBRARY
}


TO THE OFFICE OF GRADUATE STUDIES:

The members of the Committee approve the thesis of

Connie Finley, Kay Jemigan, Bonnie Hogan, Effrosini Rotous and Daryle Steffen presented May 15, 1970.

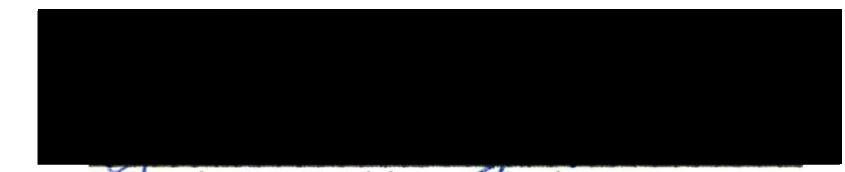

Robert s. Justice/ thairman

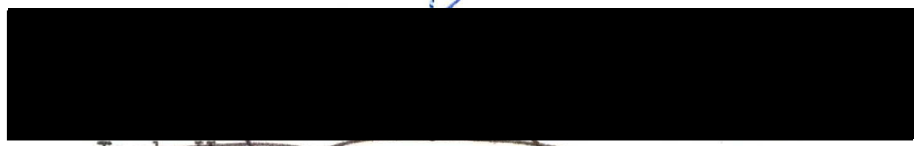

Jaek Hegrepes

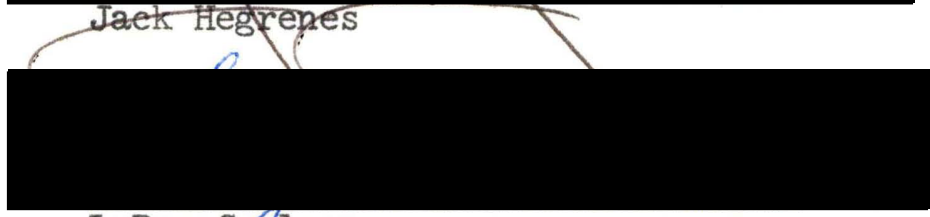

LeRoy Cafison

APPROVED:

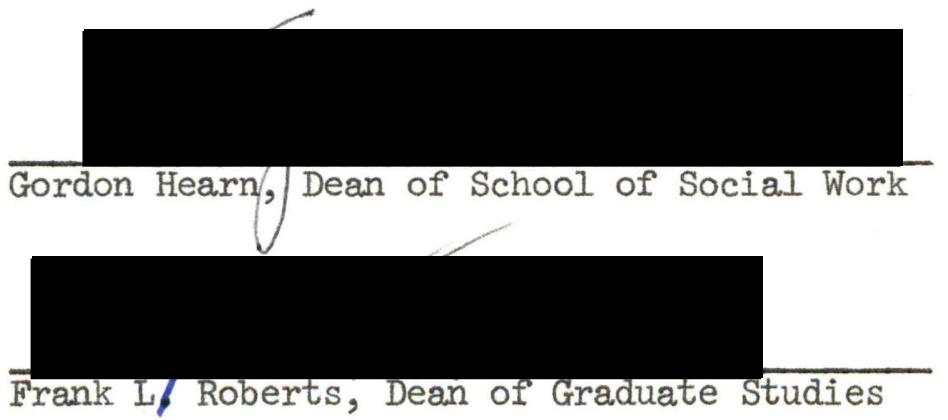

May 15, 1970 


\section{ACKNONLEDGMENTS}

The writers wish to express their apprecjation to the following: the University of Oregon Medical. School, Crippled Children's Division, especially Dr. Wilma, Carson and her staff, who made available the case records for this study, Mr. Ted Grams, who offered his technical advice on the census tract, and the families who allowed us the privilege to interview them.

We are especially grateful to Dr. Robert Sidney Justice, our fac. ulty advisor, for his encouragement and invaluable guidance. His continued interest and suggestions insoired the group toward completion of this research project. 
TABIE OF CONTENTS

PAGE

ACKNOTLEDGMENTS . . . . . . . . . . . . . . . . . ii

IIST OR TABLFS . . . . . . . . . . . . . . . . . vi

IIST OF FIGURES . . . . . . . . . . . . . . . . vix

CHAPTER

I MENTAT RETARDATTON: AN INTRODUCTION . . . . . I I

Statement of the Problem .......... . . . 4

Revien of Pertinent Iiterature . . . . . . 5

Study question.......................... 8

Study Hypotheses.............. . . 8

II THE STUDY DESIGN . . . . . . . . . . . . 9

History and Operation of the University

of Cregon Medical School-Crippled Chil-

dren's Division (UOMS.CCD)......... 9

Description of the Community . . . . . . 12

Selection of the Sample . . . . . . . . If

Source or the Deta . . . . . . . . I8

Procedures . . . . . . . . . . . . 19

Contacis with the Study Families . . . . . 20

Derinition of the merms and Concepts . . . . 21

Fecording and Anazysis of tre Data. . . . . 22

Study Iimitations . . . . . . . . . 22 
Analysis of Criterion and Variables . . . .

Discussion of Research Questiors and Hypotheses . . . . . . . . . . . 57

Other Findings . . . . . . . . . . . . 63

IV SUMMARY AND IMPLTCATIONS . . . . . . . . . . . 65

Implications of the Study . . . . . . . . 67

BIBIICGRAPHY . . . . . . . . . . . . . . . . . . . . . . . . . 69

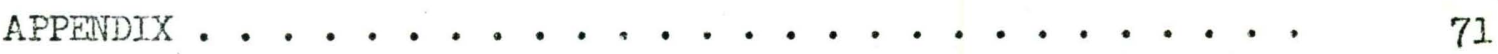


I Age by Sex . . . . . . . . . . . . . .

II Age by I.Q. . . . . . . . . . . . . .

III I.Q. by Race . . . . . . . . . . . . .

IV Number of Children in Family . . . . . . . .

$\mathrm{V}$ Patients Rank Among Siblings in Family . . . . .

VI Father's Age by Education (Years) . . . . . .

VI Mother's Age by Education (Years) . . . . . .

VIII Occupation Status of Parents . . . . . . . . 32

IX Family Income . . . . . . . . . . . . . .

X I.Q. by Source of Referral . . . . . . . .

XI Source of Referral by Sex . . . . . . . . . 34

XII Source of Referral by Age . . . . . . . . .

XIII Source of Referril by Resources Families Continue to see Currently . ..............

XIV Number of Clinic's Recommendations by Specific Diagnosis . . . . . . . . . . . .

XV I.Q. by Number of Recommendations by Clinic . . .

XVI I.Q. by Number of Recommendations . . . . . .

XVII I.Q. by Specific MedicaI Diagnosis . . . . . .

XVIII Patient's Age Vs. Following of Recommendations . . . 4 I

XIX I.Q. Vs. Following of Recommendations . . . . . 42

XX Farnily Structure Vs. Recommenations Followed. . . 43

XXI Father's Age Vs. Following of Recommendations . . . 44 
TABI,E

XXII Mother's Age Vs. Following of Reconnendations . . .

XXIII Father's Occupation Vs. Following of Recormendations . . . . . . . . . . . .

XXIV Mother's Occupation Vs. Following of Recomendations . . . . . . . . . . . . .

XXV Income Vs. Following of Recommendations . . . . .

XXVI Home Ownership Vs. Following of Recomendations . .

XXVII Education Vs. Following of Recommendations . . .

XXVIII Source of Referral. Vs. Following of Recommendations . . . . . . . . . . . . .

XXIX Useabizity of Clinic Recomendations Vs. Following Recommendations . . . . . . . . . .

XXX Presentation of Recommendations Vs. Following

Recommendations . . . . . . . . . .

XXXI Areas Which Clinic Was Helpful Vs. Following

Recommendations . . . . . . . . . . .

XXXII Dissatisfaction of Clinic's Program by Parents

Vs. Following Recommendations . . . . . . .

XXXIII Degree Clinic Helped Parents to Understand Child

Vs. Following Recommendations . . . . . .

XXXIV Changes in Child and Family Life Vs. Following

Recommendations ..............

XXXV Relationship of Following of Clinic Pecomen-

dations to the Income of the Farents . . . . 
XXXVI A Relationship of Following Clinic Recommendations to the Father's and Mother's Education . . . . .

XXXVI B Relationship of Following Clinic Recomendations to the Father's and Mother's Fducation ......

XXXVII Relationship of Following Clinic Recomendations to the I.Q. of the patients.......... 


\section{LIST OF FIGURES}

FIGURE

PAGE

I Census Tracts NuItnonah County . . . . . . . . 


\section{CHAPSER I}

\section{MENTAT, REYARDATION: AN INTRODUCTION}

Mental retardation is a national social welfare concem. The Unjted States Department of Kealth, Education and Velfare estimated in 3962 that trese were five miluion mentelly rotarded individuals in the nation. It was also estimated that there will be six milizon mentaliy retarded individuals in the country by 1970, half of whom will be chil dren. It is s significant social concern since institutions provide care for approximately oniy $4 \%$ of the nation's mentally retarded. ${ }^{2}$

There is increased movenent away from the use of institutional care for the mertally retarded because of the expense involved and because society is growing to recognize a responsibility for providing resources which will enable the retarded to become a productive, lew abiding member of society and as fully functioning a human being as his potential will allow. 2

An increased awareness of the prevalence of mental retardation in the ration lod to recognition of the fact thet federal leadership and financine were vital if this social concern was to be deant with effectively. Federal legisiation has been enacted which allocated funds for

Irhe Secreusry's Comnitiee on Nenta? Retardation, Menta? Retardation Programs of ine U.S. Department of Health, Fucation and Welfare (Weshington, U.S. Departmert of Healtr, Education ard Welfare, Feb., 1962), p. 11 .

${ }^{2}$ Robent Sidney Justice, "Coping Patterns of Parents of Mentally Retarded Children" (unpublished doctoral dissertetion, University of. Southern Cajfornia, June, 1968), p. 2. 
the development of research centers, for the improvement of hospital programs, for demonstration and pilot projects, and for the education of professional personnel. Federal funds were made available to states in 1963 for the purpose of developing comprehensive coordinated plans to deal with mental retardation on a statewide basis. 3

The Oregon Association for Retarded Children is a member of the National Association for Retarded Children. OARC is composed of local county units in the state of oregon and is active in behalf of Oregon's mentally retarded. In Sestabrooke's "President's Yearly Report to the Membership" of OARC, 1969, it was found that the area of emphasis during the past year has not coincided with the NARC's emphasis upon res. idential care for the mentally retarded. 4 During the past year oregon Association for Retarded Children has been instrumental in obtaining Title VI funds totalling $\$ 126,765.00$ which has been allocated to a variety of programs for Orecon's mentaliy retarded. Also, according to the president's report, a federal grant through the Department of Montal. Health to OARC will provide for a teacher training program on behavior modification. A pilot project for enploying mentally retarded in government agencies has been successful for the past four years on a federal. level, and the president of the Oregon Association is dso working toward a strong OARC which could implement such a demonstration project in Oregon.

On a state level, the Oregon Association has also been very active

\section{Justice, 20e. cit., p. 3.}

4"The President's Yearly Report to the Mernbership", 1969 Annual State Convention, May 16, 1969 , A. Lee Sestabrocke, Fresident of OAPC. 
in encouraging progressive legislation for the mentally retarded. During the 1969-70 session, a total of eighty-eight bills were introduced in the legislature which related to mental retardation in sore manner. Two major bills were enacted into law; House Bill 1217 relating to the trainable retarded, and House Bill 1253 relating to parental financial responsibility. House Bijl 1217 provides for contracting with the public schools and public or private asencies for education for the trainable retarded and for counseling for parents or guardians. House Bill 1253 limits parental financial responsibiliti for institutionalized children. It provides for a fee seale to be detemined by the court based on net receipt of income tax; parents are required to pay until their child is 21 or for a 10 year period, whichever occurs last, 5

On a courty level, the Nulnomah Association for Retarded Children was organized as a parent's movement in 2953 . It preceded the develorment of OARC and was knom as the Portland Association for Retarded Children until 1967. It grev from a membership of 12 parents to over 600 parents and is financed by membership dues, contributions, and the Tri-County United Cood Neighbors. According to MARC, there were an estinated 3,300 school-age mentally retanded children in the City of Portland alone in 1.967 .6 Accoraing to the same source, there were also 1,000 children and adults fron Multnomah County served at Oregon Fairview Horne in Salem, cregon. 7

\section{Ioid.} 1967.

6Multnomal Association for Retarded Children (pemphlet), June, 7I Ibid. 


\section{STATEMHNT OF THE PROBLER}

Those clinics and institutions wich are responsible for developing programs for the mentally retarded are concemed vith providing the best possible services for the retarded and their femilies. However, there has been very little information gathered about how the recipients of these services pereeived then and the degree to which they vere able to utilize then. Therefore, the present study was undertaken for the purpose of exploring perental attitudes toward the services their children received as they were evajuated at the University of oregon Medical School-Crippled Chilaren's Division Clinic (JOMS-CCD). Particular interest has been directed townd the utilization of clinic recomendations and the impect of tho Clinic's services upon subsequent fanily ifie. Sone of the variables which might heve affected the utiligetion of reccrmendations are:

a) the degree of retardation of the child,

b) the Ievel of parental education, and

c) the level of fanity income.

However, in the process of this study other rariahles were discovered to heve significant infuence won parental decisions about whether or not to follow through with clinic recomendatiors.

It we: felt that this study woula provide signifient infometion about how the consuners of the clinic"s sorvices perejved them end the extent to which they were abic to utilize them. Since pronts, in nost Instrances, are those most drectly involwed in the cone and planing for the retanded child, it seemed most jmontant in an evaluetion of exist ing programs to determine how they viewed the strengths and weaknesses 
of those services available to them. It is expected that the information collected in this study will be helpfur in providing a basis for jmprom ving the services currentiy extended by the UOMS-CCD Clinic to retarded. children and their families.

\section{REVIEN OF PERTINENTP IITERATURE}

Review of the literature has been undertaken in the area of parents' evaluation of the clinical services. Studies in this area are relevant to the present study.

James Grant, MSW and Evelyn Smith, MSW in a study at the Child. Develoyment and Mental Retardation Center, investigated the parents" action on clinic recommendations for adaitional psychiatric or social work service. They mentioned there that "although mental retardation diagnostic clinics do make referrals for psychiatric or sceial work services, there are no studies published on factors related to continuance or discontinuance in treatment from such referrals. "P

The above authors found a significant correlation between the father's education and the following of recomendations. However, education of the motber did not relate to continuance in treatment.

They a.1so found that those parents who participated in church activities are nore likely to continue than those who do not $(p<.05)$. Arother variable that they found to influence the following of recommendations was the clarity with which the recommendations were nede. Sev-

BJames Grant; and Evelyn Snith, "After Diagnosis-What?" Child Development and Mental Retardation Center. University Hospital, University of Washington (umpublished pamphlet).

9rbid., p. 2. 
eral other authors have also pointed out the need for clarity. (Berclay et al.,10 Graliker, 11 McIntire12).

Some additional. findings in this study are that parents of children under five years old were more likely to discontinue treatment than the parents of older children, although this was not statistically significant. Also parents of children diagnosed as mildiy mentally retarded discontinued treatment on did not follow the recomendations.

Some of the variables used in the ebove study are also used in the study at the UOMS CCD Clinic. These are: education of parents and IQ of children. Furthemore some of the other questions in the study by Grant and Snith ere also explored in the present study.

Barclay and essociates reported a study in which parents evaluated. the clinical services provided to their retarded children. Purpose of this study was to help the staff in evaluating the adequacy of services and also to find out how services can become more effective. The findings suggested that careful consideration of the psychological implications of the total diegnostic and evaluative process can expand knowledge of the underlying attitudes of parents that detemine how effectively services can be implemented.13

10A. Barclay, I.R. Goulet, M.M. Aoltorewe, and A.R. Sharp, "Parental Evaluation of Clinical Services for Retarded Children," American Joumal of Mental Deficiency, 67, No. 2, (S'ept. 1962), 232-237.

I.B.V. Graliker, A.H. Parmalee, and R. Koch, "Attitude Study of Parents of Mentally Retarded Cniliren: II. Initial Reactions and Concerns of Parents to a Diagnosis of Mental Retardation," Pediatrics, 24, (1959), 819-821.

12M.S. McIntire and T.C. Kiekhaeker, "Farental. Reactions to a clinic for the Evaluation of the Mentally Retardea, "Nebraska Medical Journal, 48, (1953), 69-73.

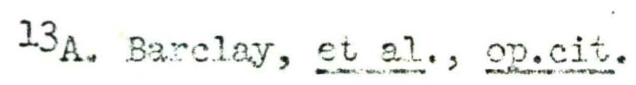


A similar study was conducted by Caldwell, et al., in which also clinical services were evaluated. A questionnaire was sent to both parents and representatives of the agency. The question was whether the clinic was fulfjuling its objectives. 14 In the analysis of the results for this study, there was no association between the degree of satisfaction and clinic variables or number of children in the family. There was a signifjcant correlation between the higher level of intelligence and younger age of the child, with greater parental satisfaction with clinic services. 15

Koch, et al., conducted a, study in which the parents' attitudes toward previous medical care was investigated. He used a sample of one hundred and five families of which the children had been seen in a special clinic for the retardate. What parents were told and How parents were told about their child was investigated in the study. It was shown in the findings that the parents were looking for a diagnosis and more information about the nature of mental retardation. As a result of these findings senior medical students had now to put emphasis on the etiology of mental retardation as well as on parental counseling. 16

3.4B. Caldwell, E. Manley, and Y. Irisson, "Reactions of Community Agencies and Parents to Services in a clinic for Retarded Children," American Journal of Mental Deficiency, 65, No. 5, (March, 1961), 582589.

I5Ibid., $590-594$.

3.6R. Koch, B. Graliker, R. Sands, anà A. Parrialee, "Attitude Study of Parents wi.th Mentally Retarded Childaen: Fvaluation of Parental Satisfaction with the Medical Care of a Retaried Child, "pediatrics, 23, No. 3, (March, 1959), 582-584. 


\section{STUDY QUESTIONS}

The specific research questions posed for investigation in this study are:

1. Is higher income positively correlated with following clinic recommendations?

2. Is the level of parental education affectirg the following of

- Clinic recommendations?

3. Is the IQ of the patient related to the following of olinic recommendations?

\section{SIUDY HYPOTHESES}

Three hypotheses were developed in order to accomplish our purpose and answer the specijic research questions which were posed.

1. $\mathrm{H}_{0}$ There is no difference between incone categories (above, below, median) and the following of Clinic recommendations.

$\mathrm{H}_{1}$ There is a difference between income categories (above, below, median) and the following of Clinic recomendations.

2. Ho There is no difference between educational levels of father and mother and the following of Cinic recommendations.

$\mathrm{H}_{2}$ There is a difference between educational levels of father and mother and the following of Cliric recommendations.

3. $H_{0}$ There is no difference in the level of IQ of the child and the following of Clinic recomendations.

$\mathrm{H}_{3}$ There is a difference in the level of $\mathrm{I} 2$ of the child and the following of clinic recommendations. 
CHAPIER II

THE STUDY DESIGN

\section{History and Operation of the University of Oregon Medical School- Crippled Cnilaren's Division}

In 1963 a pilot program for mental retardation diggnostic services was established at the University of Oregon Medical School-Crippled Children's Division (Uois-CCD). This program vas the result of a dialogue between personnel Prom the Crippled Children's Division and the University of Orecun Syecial. Educetion Department regarding mental retardation services for children. The phizcsophy of these concerned people can be best described in the folloning quote:

\footnotetext{
"Each child that is mentally retarded must be in as neax a normal physical state as possible before he is able to learn to his maximum capacity."I
}

In 1964 the stafr's discussion culminated into a grant application from public health for a University affiliated center in mental retardation. The facility was to have a program focusing on diagnosis and clinic and teaching functions with the mejor emphasis on training propessional persons to function in multiple discipline prograns with the mentally retarded. The program was to emphasize the continual investigation of of diagnosis and treatment procedures utiijzed in working with retarded

Irom information compiled by the UOMS-COD Clinic and distributed in the form of a brochure. 
children. A crucial aspect of the program was an examination of results in clinic processes, parent education training and follow-up activities. 2

A planning grant was received from the Kennedy Foundation in 1964-65 to develop a training grant. Training support from the Children's Bureau was received in December, 1967. Presently, the center is being funded through a $\$ 560,000.00$ Children's Bureau grant. The center is a multi-discipline clinic where members of nany different professions work together with both the child patient and the parents. It is staffed by people from the following professions: medicine, speech, dentistry, nursing, social work, psychology, audiology, occupational therapy, physical therapy, nutrition, speciai education, and genetics. 3

Various kinds of services are provided by the UOMS-CCD. An active program of evaluation and linited treatment designed to help parents better understand and develop the child's abi]ities as much as possible are the primary services provided by the Clinic. Presently, the Clinic can only provide outpatient care. When the new building, which is currently under construction, is completed, inpatient services will be established at the facility. To keep the community abreast of activitics and services of the clinic, faculty nembers make presentations at institutes in the community for public welfare caseworkers, speech clinicianș, physicians, and student nurses. Occasionally the Clinic has short educational programs for dieticians, dental hygenists, Iicensed Practical Nurse volunteers, special education students, aids, and staff from the

\section{${ }^{2}$ Ioid.}

3Ibid. 
state mental retardation residential facility, college and high school students. ${ }^{4}$

When a child is to be evajuated by the Clinic, the entire process is divided into two sections. During Phase 1, which is a six week prom gram, the primary mission is outpatient diagnosis and treatment services. To accomplish this ten children are adnitted to the program for a diagnosis. Five mornings for five weeks the children are functioning in a diagnostic classroom with the supervision of a special education teacher from 8:45 to 11:30 A.M. Throughout this time period students are taken indivịdually and as needed by clinicians from the various disciplines for a specific diagnostic evaluation. The classroom educational activity is devoted to observation and task performance.

Also during Phase 1 parent-education services are provided both on a group and individual basis. During the first three weeks parent meetings are held to orient the parents to some of the procedures and test elements that the various disciplines use to evaluate the children. Mothers' and fathers' groups are organized to help parents work through some of their feelings and concerns about their child and the total family. During the sixth week, parents have two conferences with staff. One is with the staff concerned with the physical well-being of the child such as medicine, speech pathology, dentistry, and audiology. The other is with the staff concerned with the socio-psychological aspects of the child's functioning and includes psychology, social work, education and nursing. Other disciplines associated with the Clinic have had. their summary conferences prior to the sixth veek. However, during these

irid. 
last two conferences an integrated diagnosis and recomendation is given to the parents. After Phase 1 is completed there is a post-program parent conference to help parent integration of diagnostic findings. The parent group continues meeting once a week for three weeks in a group or individually after the completion of Phase 1.5

Phase 2 of the program involves assigning of families to social workers and psychologists when social and enotional problems exist within the family. Individual and group treatment programs are available to the parents if they so choose. 6

These are the diagnostic services which the UOMS-CCD provides the mentally retarded child and its parents. This particular research group has done a follow-up study on 100 randomly selected families who have used the facility and its scrvices to determine how effective and useful the Clinic has been to the consumer.

\section{Description of the Community}

The Area: Historically, the Oregon econorny has been largely resource-oriented to forest and agricultural products. Early industries were fur tradirg, fishing, logging, and farming. 7

The Portland area later grew to be a major distribution center for consumer goods and raw materials. However, in the past decade the economy of the area has been changing from primarily a distribution and ser-

\section{Ibid.}

$6_{\text {Ibid. }}$

7 State of Oregon, Departinent of Conmerce, Economic Development Division, The Oregon Economy and Outlook, 5th ed., March, 1968. 
vice center to a growing manufacturing area, with impressive rates of growth in employment and output in manufacturing industries such as machinery, electronics, and fabricated metal products. Employment in these industries is increasing three and four times faster than the population growth in the area. 8

Because of a well diversified economy, the well-being of the area is not wholly tied to any given industry. In order of importance it is impossible to rank oregon's industries beyond the first three which are (1) Sorest products, (2) agriculture, and (3) tourism.9

Portland is Oregon's Iargest city, located on the Willamette River near its confluence with the Columbia River. It is 65 airline miles from the Pacific Ocean or 110 miles by deep-draft navigation by the Columbia River. It is the economic and financial center of the Metropolitan Portand region and is a major manufacturing and distribution center. The portland urban area covers 436 square miles and the standard Metropolitan area covers 3,663 square miles. Industrial areas are heavily concentrated around the Columbia and Willamette Rivers in Portland. There was a $6.5 \%$ increase in total manufacturing employment in Metropolitan Portland during the sumer of 1969 , as compared with $2.6 \%$ in the nation. 10 The total male and fonale employees in the labor foree within the city limits was 149,796 of which 116,128 were private wage and salery workers, 13,060 were goverment workers, 14,690 were

\section{$8_{\text {Ibid. }}$}

9Ioid.

10Portiand, Oregon Industrial Location Facts File, Greater Fortland Area, The Portiand Chamber of Comerce, Jan.; 1962. 
self-employed workers, and 918 vere unpaid family workers. 11

Within the city limits of Portland the population declined from 384,000 in 1967 to 377,800 in 1968 for a total decrease of 6,200 residents in Multnomah County just outside the city limits of Portland while the total population for the Metropolitan Portland area (which includes Multnomah Clackamas, and Washington Counties in Portland as well. as Clark County in the State of Washington directly on the opposite side of the Columbia, River from Portland) during this same period was increased by 26,945. The growth trend for Metropolitan Portland showed a population increase of $16.6 \%$ during the $1950-60$ decade as compared. with an increase of 21.1\% during the 1958-68 decade. 12

The median for the number of school years completed for this population was 12.0 (this median was the same for the whole of Multnomah County and nearly the same for the Metropolitan Portiand area). Of the total population of 372,298 within the city limits, 35I,379 were classified white $(94.4 \%), 15,637$ negro $(4.2 \%)$ and 5,282 other $(1.4 \%)$ (American Indians, Japanese, Chinese, Filipinos, Koreans, Asian Indians, and Malayans) .13

Resources: A full gamut of services is offered in the community. Major social services, both tax supported and privately supported, which serve the people of Clackama, Multnomah and Washington Counties cover the following subjects: aged, alcoholism, child welfare, employment and

1H.S. Bureau of the Census, U.S. Census of Population and Housing: 1960; Census Tracts, Final Report PHC (1)-I2I (Portland), U.S.G.P.O., 1962.

12 Ibid.

13U.S. Eureau of the Census, op.Cit. 
job training, family and personal probiens, unmarried mother services, financial assistance, services for foreigners, handicapped, housing, inter-group services, legal advice, medical care, recreation and informal education, and veterans and armed forces. The iri-County Community Council promotes the development, extension or modification of health, welfare and recreation services in accordance with community needs. 14

To promote the general welfare of mentally retarded persons, there is the Multnomah Association for Retarded Children (MARC). It encourages development and expansion of services through public, private and religious organizations, sponsors and pronotes programs for the retarded, and educates the public and parents of the retarded in better understanding of the problem through group meetings and special programs. It is a central resource of information regarding other prow grams for the mentally retarded in the comrunity. 15

Resources for retarded children within the city limits of Portland are varied, some of them encumbered with waiting lists and fees to parents, and heavily reliant upon private philanthrophy. Some of the services offered are also limited in respect to the degree of retardation or its accompanying handicaps. Scholarship funds are sometimes available to parents through MARC or other private sources to help defray costs of services but such funds are limited. 16

14"Where to Iurn," a directory of health, welfare and recreation agencies, prepared by the Tri-County Community Council, 718 W. Burnside Street, Portland, Oregon, September, 1968.

15 Information gathered from pamphet and discussion with representative at MARC office, Commaty Service Center, $718 \mathrm{~W}$. Burnside Street, Portiand, Oregon

16Information gathered from pamphet and discussion with representative at MARC office, Comunity Service Center, $718 \mathrm{~W}$. Burnside Street, Portiand, Cregcr 
There are camping programs sponsored by various groups such as The Salvation Army, Kiwanis, Easter Seal Society, Bureau of Parks, and Oregon Association for Retarded Children. Neighborhood House, Inc. offers recreation activities for both physically and mentally handicapped children from the ade of three ycars upward. The Bureau of Parks sponsors the Mr. Portland Program which provides a ten week summer program as well as daily recreation programs throughout the area during the entire year for retarded children. Sometines they use public facilities but always provide their own personnel to conduct the programs. 17

Among those private school programs for the trainable retarded are Timmy Educational Center which is under the auspices of the Model Cjties Program; Foecker Day School under the auspices of Westminster Presbyterian Church which has a $\$ 60.00$ monthly fee; Pilot Educational Program with a monthly fee of $\$ 35.00$; Neighborhood House which has a. fee of $\$ 18.00$ anmually and provides an every day living course for retarded children twice per week (parents pay for the cost of supplies); and then the following schools which all charge a monthly fee of $\$ 50.00$ : Portland Children's Center, Fmily School for Retarded Children, Flevel Drive Day Nursery, Happy Hollow Children's Center, and Jewish Community Center (Pre-School) wich serves only about 20 retarded children. 18 The Portland Public Schools, District H1, provide special classes for the educable mentally retarded in twe?ve high schools and in thirty elemen-

17Information gathered from pemphlets available at MARC office and telephone discussions with representatives of Bureau of Parks and Neighborhood House.

28Information gathered from ranchlets and discussion with representative at MARC office. 
tary schools within the city. Although they are considering the addition of trainable programs to the special class system, a trainable program was not available through the public schools at the time of this writing. 19

Private residential facilities for the retarded include Happy Hollow Children's Center, Our Lady of Providence Child Center, Waverly Children's Home, and Albertina Kerr Nursery Home. 20

There is a half-way house for retarded young men and one for young women. MARC also maintains a current list of sheltered workshops in the area, some of which serve the retarded. 21

\section{Selection of the Sample}

A random sample of 1.00 cases was selected from 232 patients who went through the UOMS-CCD prior to January, 1968 and whose parents were and are still residing in the Portland. Metropolitan area. In selecting the randon sample, the card file in the Clinic was utilized. Standards for random selection of the sample was followed. 22 In counting the cards in the file, when a non-Portland resident or foster home situation appeared, it was treated as non-existing. Each of the five students were randomly assigned twenty cases for which they gathered data from the Clinic records and then conducted the semi-structured interviews.

Iginformation obtained from representetive of Portland Public Schools, Child Service Bldg., 220 H. Fi, Beech Street, Portland.

20 pamphlets containing this infomgtion available at the MARC orfice. 2] Ibia.

${ }^{22}$ Young and Veldman, Introductory Statisties for the Behavional Sciences, 423 . 
Source of the Data

Two questionnaires were developed to elicit information that would be an aid in answering the specific research questions which were posed. Questionnaire A was designed to secure the information which would be abstracted from the Clinic records. This information included such items as the degree of retardation, the Clinic's reconmendations, identifying information about the fomily such as race, religion, and referral source to the Clinic. This iniormation was abstracted lergely from the fincl summary in the clinic records. Questionnaire A was completed prior to Questionnaire B. Both copies, A and B questionnaires can be fourd in Appendix $A$ and $B$.

Questionnaire B was completed during the 20-30 minute semistructured interview with either or both parents held in their residence. This questionnaire includes identifying itens about the backgrourd of the family: age of parents and children, education and occupation of the parents, total income of the family. Questions regerding opinion and attitude toward the helpfulness of the clinic were an important part of this questionnaire. Fxamples of this were suecifje areas in which the clinic may or ray not have been helpful such as in understamding medical questions about theix child or in planning for the child's future. An importart item on this questionnaire was the family's understanding and recall. of cuinic recommendations and whether they could have been presented in a more helprul manner. Another item on this schedule was the fanily's ability on inabiljty to follow through on the recormendations. Gestionnaire $B$ was designed to elicit responses on the part of the parents which would be evaruative of the Clinic's 
erfectiveness.

\section{Procedures}

A uniform procedure was followed in attempting to locate the study subjects. Information regarding the current address and telephone numbers of the families was taken from the card file of the UOMS-CCD Clinic. Telephone contact was made with each farnily during which a statement was read identifying the purpose of the study and an appointment scheduled for the family interview. If the families were no longer using the same telephone number, an attempt was made to locate a current address and telephone number through the 1969 Portland Metropolitan Directory. If this was not successful, atternots were made to locate a current telephone number through the information operator. If no new listing was available, the interviewers went to the family's address to determine if that was still their place of residence.

The original sample was composed of 100 families and 59 cventually proved to be accessible for the study. The 40 families that vere inaccessible fell into the following categories:
a) Cannot Jorate: 19
b) Moved out of town: 7
c) Outside of city linits: 7
d) Refused interview: 4
e) Clinic adrised against contact: 2
f) Moved to foster care: I.

The first category, "Cannot locate", was determined by following the procedures described above. Seven fanilies fell into the category "Moved out of town", with information regarding five of the families 
secured from neighbors. The Telephone Company gave information that one family had left the city and information regarding the last family was secured from the card catalogue at the Clinic.

\section{Contact with the Study Families}

Initial contact with the study families was made by telephone during which time the student identified himself and described the pur.pose of the study and the auspices under which it was being conducted. Emphasis was placed upon the fact that the students did not directly represent the UOMS-CCD and that confidentiality would be maintained if the family chose to participate in the study. The following introduction was stated to each family. (see Appendix B, first paragraph) During this telephone contact, an appointment vas arranged with the parent in their home in order to complete Questionnaire $B$.

The semi-structured interview with the mother lasted approximately 20-30 minutes. When meeting the parent in their home, identification of interviewers, the purpose of the study, and the auspices under which it was being conducted was again repeated. The parent was informed that the interview would be structured and the questions to be read to the interviewce from the interview schedule. The final page of Questionnaire $B$ was left unattached during the interview. It had been devermined that the impression of the interviewer regarding the parent's degree of cooperativeness would be rocorded following the interview. It had also been determined that the parent should have access to the questionnaire if they wished to read it during the interview. An attempt was made to keep the attention focused on responding to the questionnaire. If the parent asked questions regerding her child's current needs, a referral 
was made to the UOMS-CCD. At the completion of the interview, gratitude was expressed for the coopexation in the study.

\section{Definition of Texms and Concepts}

Income. Total approximate income from all sources. Income was broken dow into seven categories.

IQ. Profoundly retarded children were defined as having an intelligence quotient of less than 20, severely retarded as those with an IQ of 20-35, moderately retarded as those with an Il of 36-52, mildily retarded as those with an IQ of $53-68$ and borderline as those with an intelligence quotient of $69-83.23$

Clinic Recommendations. The recomiendations given to the parents in a conference at the end of the six veek evaluation period by the Clinic staff. The recommendations found in the records which the clinic made about any particular child feli into the following eleven catego ries:

\section{1) Special School}

2) Counseling

3) Special Care

4) Recreational Therapy

5) Physical Therapy

6) Dental Care

7) Speech Training

8) Special Diet

9) Hearing

23Helen Rick, "A Nanual on Teminology ana Classiftication in Menm tal Retardation," Mongr. Suppl. to American Journal of Mental Deficiency (2nd ed., 1961), 59. 


\section{0) Eyre Care}

11) Others (Medication, Behavior Control, Surgery, Neurological clinic, Foot Care)

\section{Recording and Arelysis of the Data.}

The nature of this shdy, being a survey, was descriptive as well as exploratory. It was descriptive in the sense that it attempted to determine how helpful the dinic had been to this sample of families. It was exploratory in that hypotheses were developed to test whether certain factors hinder or raciljtate the following of recomendations on the part of the parents. Additional rypotheses derived from the date can be tosted in future studies, Conscquentiy the andysis of the date has taken two principle forms, descriptive and inferential.

Responses of the interviewees were recorded by the intervievers at the tine of the interview. There was also space provided in the ques.. tionnaire for the open ended questions. Seventeen tables based on the recommendations were constructed and frequencies were tabulated by hand. Eighteen additional descriptive tables vere constructed in wich descrip tive data was recorded. This derographic data, such as age, sex, marital status was then cross-tabulated with clinic recomendation, end degree recomendations were followed.

To test for the relationsh betreen the criterion and the different variables the chi square test of association was employed. The or: .05 level of sigrificance was set in auvance of the coliection of the Bata.

\section{Study Limitations}

Most of the data biained in this swoy was sough retrospectively. 
The interviewees had to mention recomendations given to them in the past, and recall feelings and difficulties they experienced in the past. Memory necessurily plays an important role. A number of them might have forgotten what happenel in the past or might be unable to perceive things the sare way at the present time. This presents a linitation in the study.

A second limitation is that the findings of this study apply only to families residing in the Portland Metropolitan area where this study was conducted. It is not know how families from other communities who heve utilized the UOMS-CCD Clinic, respond to recommendations. Distarce from the clinic as well as availability of resources in those commuities might be sorne additional factors to hinder or facilitate following of recomendations. Therefore, to generalize these findings to other communities would have to be done nost cautiousiy.

Another limitation is the inaccessibilitu of a great number of people included in the sample. There were 19 cases we could not locate, 7 that had moved out of tom, 7 which were outside city limits, who refused to be interviewed, 2 which the elinte advised us not to contact, and I which had moved to foster home. The largest category was composed of fanilies who could not be located at their former addresses.

A problen we faced during the collection of the data, was with regard to the incomplete and non-standardized records that the clinic keeps, i.e., lack of social histoxy, source of reaerral. It was atterpted to complete this by obtainirig the information during the interview. 


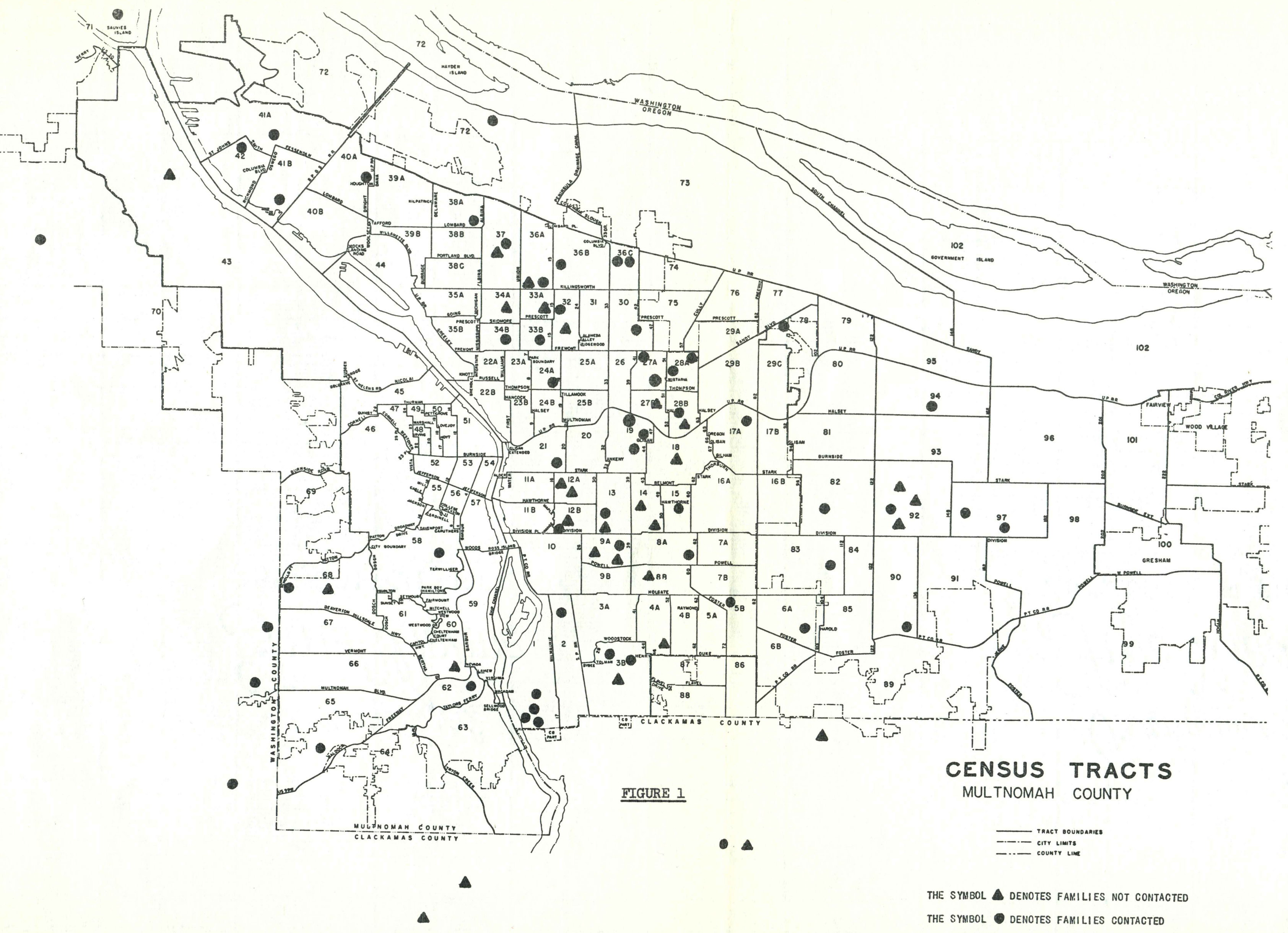


CHAPTER III

\section{ANALYSTS}

General Description of Study Population

Summary

Analysis of Criterion and Variables

Discussion of Research Questions and Hyootheses

other Findings

Chapter three will present the analysis of this study. The first part consists of an analysis of the descriptive tables followed by a profile of the typical child and his family seen at the clinic. Next an analysis of relationship between the criterion, following clinic's recommendations, and the different variables is presented. A discussion of the research questions, hypotheses, and other findings will end the chapter.

FIGURE I

LOCATION OF FAMIIIES IN STUDY

The location on a census tract of the families of retarded children used in this sample (Figure 1) shows distribution quite evenly throughout the general population, with more families located in the more densely populated area and fewer families located where the population was less. The population of this area covered a wide distribution of income and housing characteristics. For families both contacted and not contacted, the retorded population was equally scattered. 
TABLE I

AGE BY SEX

\begin{tabular}{cccccc}
\hline Age & Male & $\%$ & Fenale & $\%$ & Total \\
\hline $5-7$ & 5 & 55 & 4 & 44 & 9 \\
$8-11$ & 15 & 79 & 4 & 21 & 19 \\
$12-15$ & 15 & 45 & 16 & 52 & 31 \\
\hline & 35 & & 24 & 59
\end{tabular}

Table I compares the age and sex of the patients. This refers to age at the time of evaluation. It reveals that the largest portion of males and females in the study are adolescents. Males comprise a significantly higher portion of the latency age children than females. 


\section{TABLE II}

AGE BY $I . Q$.

\begin{tabular}{|c|c|c|c|c|c|c|c|c|c|c|c|c|c|c|c|}
\hline Age & $\begin{array}{c}\text { Less } \\
20\end{array}$ & $\%$ & $20-35$ & $\%$ & $36-52$ & $\sigma_{p}^{\sigma}$ & $53-68$ & $\%$ & $69-83$ & $\%$ & $\begin{array}{l}84- \\
\text { above }\end{array}$ & $\%$ & Unknown & $\%$ & Total \\
\hline $5-7$ & 0 & & 0 & & 4 & 44 & 2 & 22 & 1 & 11 & 0 & & 2 & 22 & 9 \\
\hline $8-11$ & 0 & & 3 & 16 & 9 & 47 & 5 & 26 & 2 & 11 & 0 & & 0 & & 19 \\
\hline $12-15$ & 1 & .03 & 2 & 7 & 11 & 34 & 10 & 38 & 5 & 14 & 1 & .03 & $I$ & .03 & 31 \\
\hline & 1 & & 5 & & 24 & & 17 & & 8 & & 1 & & 3 & & 59 \\
\hline
\end{tabular}

Table II compares the age and I.Q. of the patients at the time of evaluation. It reveals that the largest number of a.l age groups fall in the middle range of retardation; i.e., 36-68 I.Q. Only one patient was in the severely retarded range and only one in the dull normal range. 
TABIJE III

I.Q. BY RACE

\begin{tabular}{lccccc}
\hline I.Q. & White & $\%$ & Black & $\%$ & TotaI \\
\hline Less 20 & 1 & 100 & & 0 & 1 \\
$20-35$ & 5 & 100 & & 0 & 5 \\
$36-52$ & 24 & 100 & & 0 & 24 \\
$53-68$ & 16 & 94 & 1 & 6 & 17 \\
$69-83$ & 7 & 87 & 1 & 12 & 8 \\
84 and above & 1 & 100 & & 0 & 1 \\
Not Recorded & 2 & 66 & 1 & 33 & 3 \\
\hline & 56 & & 3 & & 59 \\
\hline
\end{tabular}

Table III is a comparison of I.Q. and race. The ratjo of blacks to whites in the Portland Metropolitan area is 1:37. This table shows that there has been a better than average representation of blacks in the progrm. This finding is supported by a recent study which found no differences between the total population and a clinic's sample for race.l

IR.S. Justice, D.S.W., M.M. Campbell, Ph.D., Gail O'Connor, M.A., Eugene Sabotta, M.A., A Look at the Population Served by a University Clinic for Retarded Children; Mental Retardation (in press). 
TABIE IV

NUMBER OF CHILDREN IN FAMIJY

\begin{tabular}{cc}
$\begin{array}{c}\text { Number of Children } \\
\text { in Family }\end{array}$ & $\begin{array}{c}\text { Sample Number of } \\
\text { Families }\end{array}$ \\
\hline 1 & 1 \\
2. & 11 \\
3 & 19 \\
4 & 13 \\
5 & 5 \\
6 & 5 \\
7 or over* & 5 \\
\hline
\end{tabular}

*Family of 15 chilaren

TABLE V

PATIENTS RANK AMONG SIBLINGS IN FAMILY

\begin{tabular}{lc}
\hline Rank & Number in Sample \\
\hline Ist & 12 \\
2nd & 2 \\
Middle & 10 \\
2nd to last & 9 \\
Last & 26 \\
\hline & 59 \\
\hline
\end{tabular}

Tables IV \& V describe the number of children in the study families and the rank of the patient among his siblings, respectively. The number of children per family occurring most frequently is "three". The largest number of patients in our study were composed of the last child born in the family. The next largest category of patients were middle children. 
TABLE VI

FATHER'S AGE BY EDUCATION (YEARS)

\begin{tabular}{lrrrrrrrrrrr}
\hline Age & $1-8$ & $\%$ & $9-12$ & $\%$ & $13-16$ & $\%$ & Over 16 & $\%$ & Unknown* & Total \\
\hline $29-39$ & 5 & 24 & 11 & 53 & 4 & 17 & 1 & .05 & 0 & & 21 \\
$40-49$ & 2 & 9 & 7 & 33 & 9 & 43 & 3 & 14 & 0 & 21 \\
$50-59$ & 2 & 14 & 6 & 42 & 5 & 36 & 1 & 7 & 0 & 14 \\
60 \& Above & 0 & & 1 & 100 & 0 & & 0 & & 0 & 1 \\
Decessed & 0 & & 1 & 100 & 0 & & 0 & & 0 & 1 & 1 \\
Unknown* & 0 & & 0 & & 0 & & 0 & & 1 & 1 \\
\hline & 9 & & 26 & & 18 & & 5 & & 1 & 59
\end{tabular}

*The "*Unknown" refers to those wives who did not know the level of their husband"s education.

**-The category "**unknown" refers to those wives who refused to discuss the issue because of a divorce from their spouse.

Table VI compares the age and education of the patients' fathers. Fathers in the middle-age range (40-59) tend to be in the higher educated bracket. The largest number of fathers in the study have had some high school and some college education. Speculation on why the younger Pathers have less education could be the lack of emphasis on higher education during this era. This is about the time 'dropouts' became increasingly high and there appears more flexibility on the need for education during the latter years than in the $50^{\prime} \mathrm{s}$. 
TABTEE VII

MOTHER'S AGE BY EDUCAIION (YEARS)

\begin{tabular}{lccccccccc}
\hline Age & $1-8$ & $\%$ & $9-12$ & $\%$ & $13-16$ & $\%$ & Over 16 & $\%$ & Total \\
\hline $27-39$ & 4 & 14 & 20 & 71 & 4 & 14 & 0 & 0 & 28 \\
$40-49$ & 1 & 5 & 13 & 62 & 5 & 24 & 2 & 9 & 21 \\
$50-59$ & 1 & 10 & 6 & 60 & 3 & 30 & 0 & 0 & 10 \\
$60-$ Above & 0 & & 0 & & 0 & & 0 & 0 \\
\hline & 6 & 39 & 12 & 2 & 59 \\
\hline
\end{tabular}

Table VII compares the age and education of the patients' mothers. The largest number of mothers in the study fall irito the secondary education bracket. It also reveals that there are twice a.s many mothers who have had some college education as those who have had only elementary education. 
TABIJE VIII

OCCUPATION STATUS OF TARENTS

\begin{tabular}{|c|c|c|c|c|}
\hline Occupation & Fathers & $\%$ & Mothers & $\%$ \\
\hline $\begin{array}{l}\text { Professional } \\
\text { Managerial. }\end{array}$ & 22 & 37 & $?$ & 3 \\
\hline $\begin{array}{l}\text { Salesman } \\
\text { Craftman } \\
\text { Operatives }\end{array}$ & 16 & 27 & 2 & 3 \\
\hline $\begin{array}{l}\text { Private Household } \\
\text { Service Workers }\end{array}$ & 9 & 15 & 7.4 & 24 \\
\hline Iaborers & 7 & 12 & 1 & 2 \\
\hline
\end{tabular}

Aid

Unemployed

Retired

Housewife

student

3

5

40

68

Deceased

Unknown

2

3

0

\section{9}

\section{9}

Table VIII shows that $37 \%$ of the fathers in the studied population held positions in the professional or managerial area, whereas only $6 \%$ of the mothers of the studied population held positions in the same category. This would seem to be expected results. Sixty-eight percent of the mothers were unemployed and remain home as housewives. 
TABLE IX

FAMILY INCONE

\begin{tabular}{lcc}
\hline Income - Yearly & Foxilies & $\%$ \\
\hline (1) Under $\$ 2,000$ & 0 & 0 \\
(2) $\$ 2,000-\$ 3,999$ & 4 & 7 \\
(3) $\$ 4,000-\$ 5,999$ & 3 & 5 \\
(4) $\$ 6,000-\$ 7,999$ & 12 & 20 \\
(5) $\$ 8,000-\$ 9,999$ & 13 & 22 \\
(6) $\$ 10,000-\$ 11,999$ & 12 & 20 \\
(7) $\$ 12,000 \&$ over & 15 & 25 \\
\hline
\end{tabular}

Table IX shows that $45 \%$ of the families studied have incomes of $\$ 10,000$ or over. This would seem to follow with the high percentage of professional and managerial positions seen in Table VIII. The average income per worker per capita in the Portland area during 1969 period of time is $\$ 4,0002$, indicating a large majority of families seen at the clinic tend to be of about the same income bracket of that of the arerage Portlander. Only $7 \%$ fell in below average bracket.

2This date was obtained from the Portland Chamber of Commerce, Research Department. Income per worker per capita is found by dividing the poputation into the states personal income tax. The average femidy in the Portland area is 3.09 . 
TABLE: $\mathrm{X}$

I.Q. BY SOURCE OF REFERRAI

\begin{tabular}{lccccccccc}
\hline I.Q. & Physician & $\%$ & School & $\%$ & Friend & $\%$ & Others & $\%$ & Total \\
\hline Less 20 & 0 & 0 & 0 & 0 & 0 & 0 & 1 & 100 & 1 \\
$20-35$ & 4 & 80 & 1 & 20 & 0 & 0 & 0 & 0 & 5 \\
$36-52$ & 8 & 33 & 4 & 17 & 3 & 12 & 9 & 37 & 24 \\
$53-68$ & 8 & 47 & 7 & 41 & 0 & 0 & 2 & 12 & 17 \\
$69-83$ & 5 & 62 & 2 & 25 & 0 & 0 & 1 & 12 & 8 \\
83 \& Above & 0 & 0 & 1 & 100 & 0 & 0 & 0 & 0 & 1 \\
Unknown & 1 & 33 & 1 & 33 & 0 & 0 & 1 & 33 & 3 \\
\hline & 26 & & 16 & & 3 & & 14 & 59 \\
\hline
\end{tabular}

Table X shows that of the cases referred most I.Q.'s fall into the 36-52 (Mild-Moderate) category. It also shows that few cases fall into the borderline or into the severely retarded category. The majority of referrals were made by physicians.

TABLE XT

SOURCE OF REFERRAT BY SEX

\begin{tabular}{lrrrrr}
\hline Source of Referral & Male & $\%$ & Female & $\%$ & Total. \\
\hline Physician & 17 & 65 & 9 & 35 & 26 \\
School & 7 & 44 & 9 & 56 & 16 \\
Friend & 2 & 66 & 1 & 33 & 3 \\
Others* & 9 & 64 & 5 & 36 & 14 \\
\hline & 35 & & 24 & & 59 \\
\hline
\end{tabular}

*The category of "Others" includes self-referrals, social service agencies, specialty clinics or the Medical school.

Table XI compares the sex of the patient with the source of referral to the clinic. The largest number of males were referred by physicians. Of females referred, an equal number were referred by schools and physicians. 
TABLE XII

SOURCE OF REFERPAI BY AGE

\begin{tabular}{lrrrrrrrrrr}
\hline Source of Referral & $5-7$ & $\%$ & $8-11$ & $\%$ & $12-14$ & $\%$ & 15 & \& Over & $\%$ & Total \\
\hline Physician & 5 & 19 & 10 & 39 & 9 & 35 & 2 & 8 & 26 \\
School & 1 & 6 & 4 & 25 & 11 & 69 & 0 & 0 & 16 \\
Friend & 1 & 33 & 0 & 0 & 2 & 67 & 0 & 0 & 3 \\
Others* & 2 & 14 & 5 & 36 & 7 & 50 & 0 & 0 & 14 \\
\hline & 9 & 19 & 29 & 2 & & 59
\end{tabular}

*The category of "Others" includes specialist clinics or the Medical School, self-referrals, and social service asencios.

Table XII compares the age of the patient at the time of evaluation with the referral source. Physicians were the largest overall referral source to the Clinic. In early adolescence, the school became the largest referral source. Friends vere a very small propor. tion of referrals. 
TABLE XIII

SOURCE OF REFERRAL BY RESOURCES FAMILIES CONTINUE TO

SEE CURRENTLY

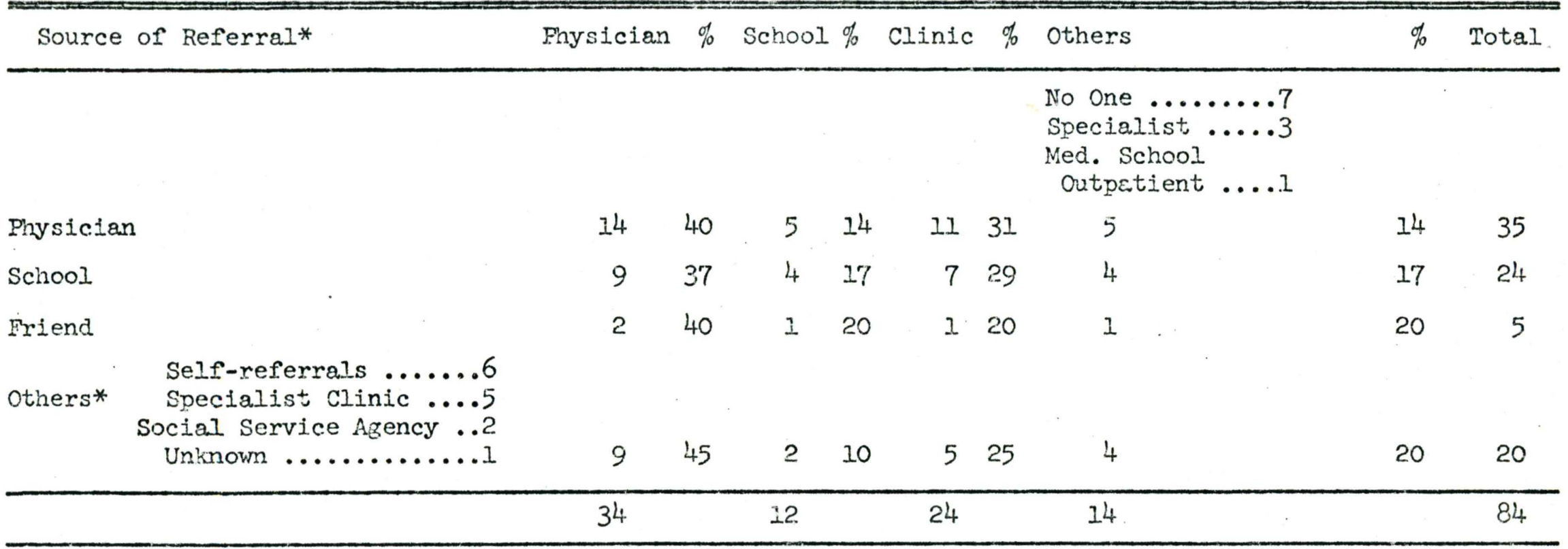

*It should be noted that families tend to consult more than one source which accounts for the total of 84 instead of the expected 59.

Table XIII compares the source of referral and the resources the family currently sees for related problems. The largest number of study families were referred by physicians and continue to consult physicians for related problems. 


\section{TABLE XIV}

NUMBER OF CLINIC'S RECOMMENDATIONS BY SPECIFIC DIAGNOSIS*

\begin{tabular}{|c|c|c|c|c|c|c|c|c|c|c|c|c|c|c|c|}
\hline \multirow[t]{2}{*}{ Recommendations } & \multicolumn{2}{|c|}{ Symptoms } & \multicolumn{2}{|c|}{$\begin{array}{l}\text { Laboratory } \\
\text { Tests }\end{array}$} & \multicolumn{2}{|c|}{$\begin{array}{l}\text { Fhysical } \\
\text { Symptoms }\end{array}$} & \multicolumn{2}{|c|}{ Syndromes } & \multicolumn{2}{|c|}{$\begin{array}{c}\text { Neurological } \\
\text { Symptoms }\end{array}$} & \multicolumn{2}{|c|}{$\begin{array}{l}\text { Speech } \\
\text { Symptoms }\end{array}$} & \multicolumn{2}{|c|}{\begin{tabular}{l}
\multicolumn{1}{c}{ No } \\
Porticular \\
Diagnosis
\end{tabular}} & \multirow[t]{2}{*}{ Totel } \\
\hline & & $\%$ & & $\%$ & & $\%$ & & $\%$ & & $\%$ & & $\%$ & & $\%$ & \\
\hline 1 & 1 & 50 & 0 & 0 & 1 & 50 & 0 & 0 & 0 & 0 & 0 & 0 & 0 & 0 & 2 \\
\hline 2 & 0 & 0 & 2 & 33 & 2 & 33 & 1 & 17 & 1 & 17 & 0 & 0 & 0 & 0 & 6 \\
\hline 3 & 1 & .06 & 2 & 21 & 9 & 50 & 3 & 17 & 2 & 11 & 0 & 0 & 1 & .06 & 18 \\
\hline 4 & 5 & 11. & 7 & 25 & 15 & 33 & 7 & 15 & 8 & 17 & 1 & .02 & 3 & .06 & 46 \\
\hline 5 & 5 & 13 & 8 & 22 & 11 & 26 & 6 & 16 & 7 & .19 & 1 & .03 & 0 & 0 & 38 \\
\hline \multirow[t]{2}{*}{6 or more } & 4 & 15 & 5 & 29 & 8 & 3.2 & 3 & 12 & 5 & 19 & 1 & .04 & 0 & 0 & 26 \\
\hline & 16 & & 24 & & 46 & & 20 & & 23 & & 3 & & 4 & & $136 * *$ \\
\hline
\end{tabular}

* See Appendix C for definition of each specific medical diagnosis.

* Kany patients were given more than one specific medical diagnosis.

Table XIV is a comparison of the number of clinic's recommendations and specific medical diagnosis. As expected, those patients who presented more symptoms received more recommendations from the Clinic. 
TABLE XV

I.Q. BY NUMBER OF RECOMMENDATIONS BY CLINIC

\begin{tabular}{|c|c|c|c|c|c|c|c|c|c|c|c|c|c|}
\hline I.Q. & \multicolumn{2}{|c|}{1} & \multicolumn{2}{|c|}{2} & \multicolumn{2}{|c|}{3} & \multicolumn{2}{|c|}{4} & \multicolumn{2}{|c|}{5} & \multicolumn{2}{|c|}{6 or More } & \multirow[t]{2}{*}{ Total } \\
\hline & & $\%$ & & $\%$ & & $\%$ & & $\%$ & & $\%$ & & $\%$ & \\
\hline Less 20 & 0 & 0 & 0 & 0 & 0 & 0 & 0 & 0 & 1 & 100 & 0 & 0 & 1 \\
\hline $20-35$ & 0 & 0 & 0 & 0 & 1 & 20 & 1 & 20 & 2 & 40 & 1 & 20 & 5 \\
\hline $36-52$ & 1 & 4 & 0 & 0 & 6 & 25 & 8 & 29 & 6 & 25 & 3 & 12 & 24 \\
\hline $53-68$ & 0 & 0 & 2 & 12 & 3 & 38 & 7 & 41 & 1 & 6 & 4 & 23 & 17 \\
\hline $69-83$ & 1 & 12.5 & 0 & 0 & 1. & 12.5 & 4 & 50 & 1 & 12.5 & 1 & .12 .5 & 8 \\
\hline 84 or Above & 0 & 0 & 0 & 0 & 0 & 0 & 1 & 200 & 0 & 0 & 0 & 0 & 1 \\
\hline \multirow[t]{2}{*}{ Not Recorded } & 0 & 0 & 0 & 0 & 0 & 0 & 2 & 67 & 0 & 0 & 1 & 33 & 3 \\
\hline & 2 & & 2 & & 21 & & 23 & & 11 & & 10 & & 59 \\
\hline
\end{tabular}

Table XV shows that the large majority of patients that were seen at the Clinic had at least three or more recommendations. The average number of recommendations per patient is 4.1 . Although the number is small there seems to be soine trend toward the lower I.Q.'s (35 or below) receiving more recommendations. Recommendations given by the Clinic consisted of such categories as schooling, counseling, institutionalization, dental care, speech therapy, special diet, recreational therapy, hearing care, and eye care. 
TABIE XVI

I.Q. BY NUMBER OF RECOMMENDATIONS

\begin{tabular}{ccccccc}
\hline I.Q. & $1-2$ & 3 & 4 & 5 & 6 & Totol \\
\hline $\begin{array}{c}0-35 \\
\text { Severe } \\
\begin{array}{c}36-52 \\
\text { Moderate }\end{array}\end{array}$ & 0 & 1 & 1 & 3 & 1 & 6 \\
$\begin{array}{c}53 \\
\text { Mild }\end{array}$ & 1 & 6 & 8 & 6 & 3 & 24 \\
\hline $\begin{array}{c}\text { Total } \\
\text { Tidal }\end{array}$ & 3 & 4 & 12 & 2 & 5 & 26 \\
\hline
\end{tabular}

Table XVI showed no statistical significance between T.Q. and number of recommendations made by the Clinic. More patients (26) were in the mildly retarded range with an arerage of 4 recommendations. 
TABLE XVII

I.Q. BY SPECIFIC MEDICAL DIAGNOSIS**

\begin{tabular}{|c|c|c|c|c|c|c|c|c|c|c|c|c|c|c|c|}
\hline \multirow[t]{2}{*}{$I \cdot Q}$. & \multicolumn{2}{|c|}{$\begin{array}{l}\text { Behavior } \\
\text { Symptoms }\end{array}$} & \multicolumn{2}{|c|}{$\begin{array}{c}\text { Laboratory } \\
\text { Tests }\end{array}$} & \multicolumn{2}{|c|}{$\begin{array}{l}\text { Physical } \\
\text { Symptoms }\end{array}$} & \multicolumn{2}{|c|}{ Syndromes } & \multicolumn{2}{|c|}{$\begin{array}{l}\text { Neurological } \\
\text { Symptoms }\end{array}$} & \multicolumn{2}{|c|}{$\begin{array}{l}\text { Speech } \\
\text { Symptoms }\end{array}$} & \multicolumn{2}{|c|}{$\begin{array}{l}\quad \text { No } \\
\text { Particular } \\
\text { Diagnosis }\end{array}$} & \multirow[t]{2}{*}{ Total } \\
\hline & & $\%$ & & $\%$ & & $\%$ & & $\%$ & & $\%$ & & $\%$ & & $\%$ & \\
\hline Less 20 & 0 & 0 & 1 & 25 & 1 & 25 & 1 & 25 & 1 & 25 & 0 & 0 & 0 & 0 & 4 \\
\hline $20-35$ & 1 & 10 & 1 & 10 & 3 & 30 & 3 & 30 & 2 & 20 & 0 & 0 & 0 & 0 & 10 \\
\hline $36-52$ & 6 & 11 & 9 & 26 & 20 & 36 & 8 & 14 & 11 & 20 & 1 & 2 & 0 & 0 & 55 \\
\hline $53-68$ & 5 & 12 & 10 & 24 & 13 & 32 & 3 & 7 & 8 & 20 & 1 & 2 & 1 & 2. & 41 \\
\hline $69-83$ & 2 & .20 & 3 & 16 & 7 & 37 & 3 & 16 & 1 & 5 & 1 & 5 & 2 & 10 & 19 \\
\hline 84 or Above & 0 & 0 & 0 & 0 & 0 & 0 & 0 & 0 & 0 & 0 & 0 & 0 & 1 & 100 & 1 \\
\hline \multirow[t]{2}{*}{ Not Recorded } & 2 & 33 & 0 & 0 & 2 & 33 & 2 & 33 & 0 & 0 & 0 & 0 & 0 & 0 & 6 \\
\hline & 16 & & 24 & & 46 & & 20 & & 23 & & 3 & & 4 & & $136 *$ \\
\hline
\end{tabular}

* Many patients were given more than one specific medical diagnosis.

** See Appendix C for specific medical diagnosis.

Table XVII indicates that more physical symptoms were diagnosed than any other category. "Physical Symptoms" refer to findings which involve eyes, mouth, ears, heart and bones. (See Appendix $C$ for further information). Those patient presenting the largest number of physical symptoms were within the moderately retarded range; i.e., 36-52 I.Q. 
PROFILE OF THE TYPICAL CHILD AND HIS FAMILY

This study reveals that the typical patient evaluated at the UOMS-CCD is a caucasian adolescent with an I.Q. in the moderate range; i.e., 36-52. The Clinic arrived at four recommendations concerning him. The study families were tyoically composed of three children and the patient's rank among his siblings was generally last. The child's mother has a high school education and is a homeraker. His father has had some college and holds a professional position. The family's income is approximately $\$ 10,000$ a year. The child was referred by a physician and his family continue to consult a physician for related problems.

\section{TABLE XVIII}

PATIENT'S AGE VS. FOLJOWTWG OF RECOMAERDATIONS

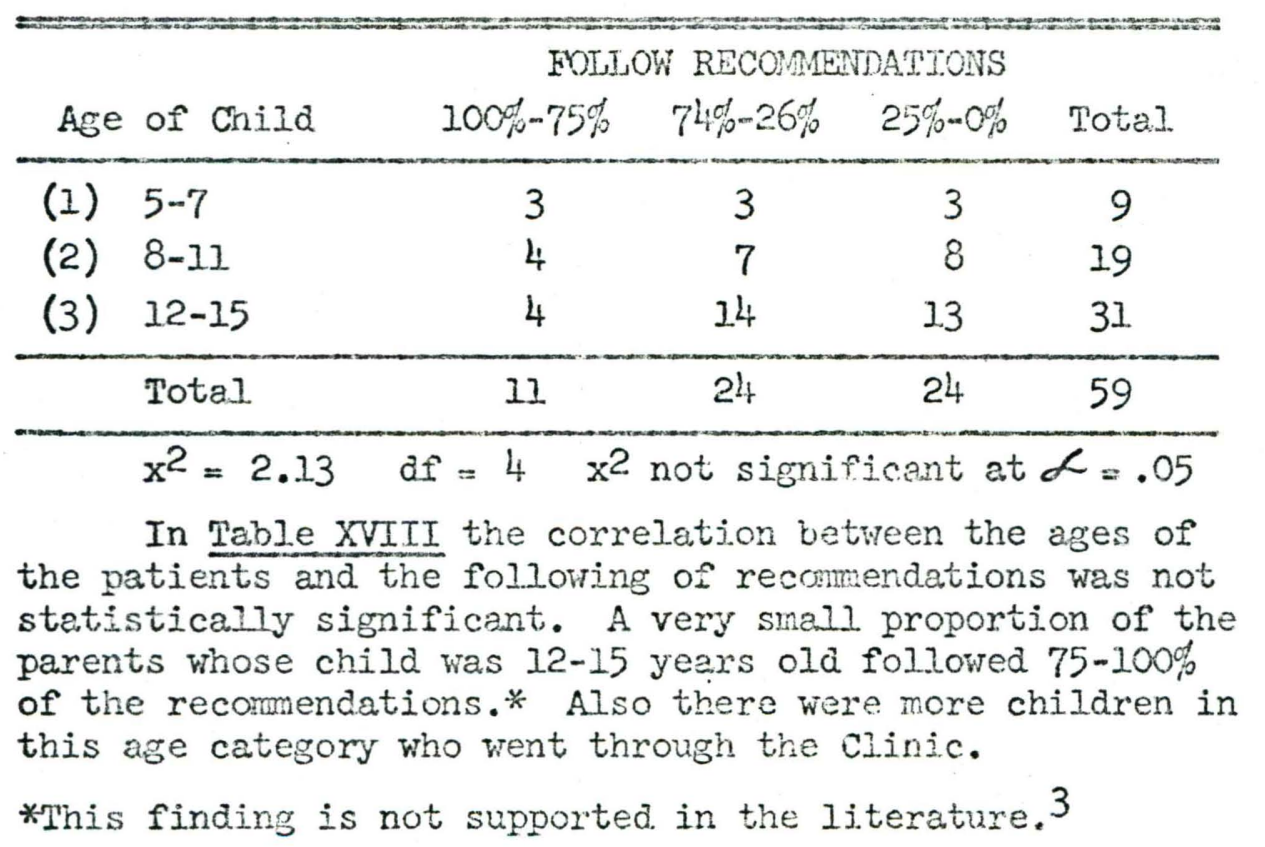

3James Grant \& Fvelyn Sroith, "After Diagnosis - What?" Child Development and Mental Retardation Center, University Hospital, Unjversity of Washington. (Unpublished pamphlet) 
TABIE XIX

I.Q. VS. FOLLOWING OF RECOMMENDATTONS

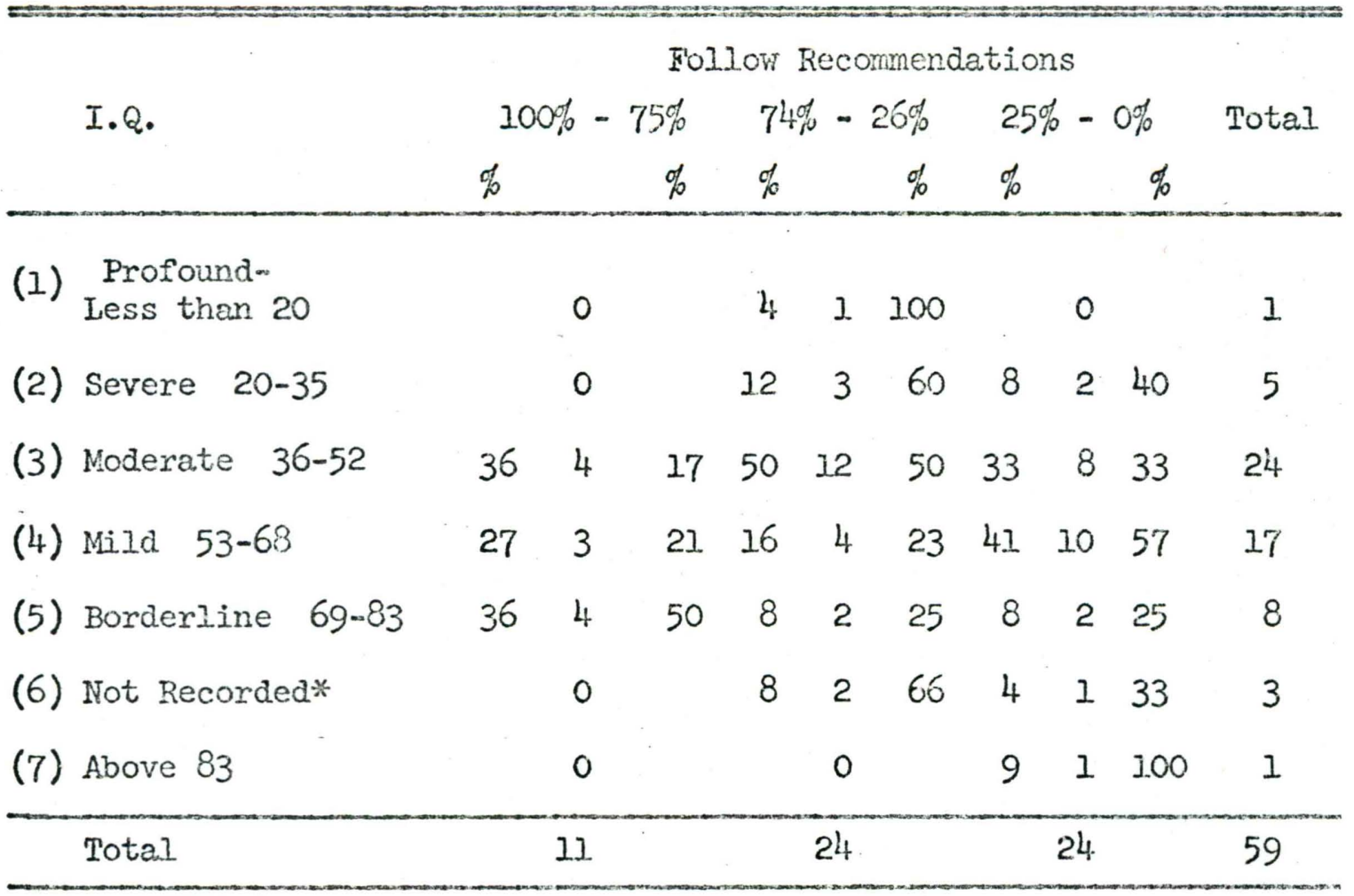

* Not included in the analysis.

Table XIX shows most of the chilaren seen at the Clinic were in the I.Q. range of moderate to mild retardation. Twenty-four of the children had I.Q.' $s$ of 36-52 and seventeen were in the range of 53-68. only one child was profoundly retarded. There is an indication that parents of those children falling in the $36-52$ I.Q. range tended to follow through with clinic recommendations more consistently than others. It is interesting to note that those in the mildiy retarded category ( $44 \%$ ) did not follow through as consistently as in the moderate category $(67 \%)$. This is seen also in the study done by Grant and Smith. 4 Reason for this can only be speculated upon. Possibly those parents of mildily retarded children more easily fit into the normal. family roles as they are able to attend regular school and lead a more normal life in the family role. The disruption in the family is not as great as they are in the more retarded child. It also could indicate those of the moderate range are more obviously retarded requiring the need to follow recommendations more consistently. 
TABLF, $\mathrm{XX}$

FAMILY STRUCTURE VS. RECOAMENDATIONS FOIJOWED

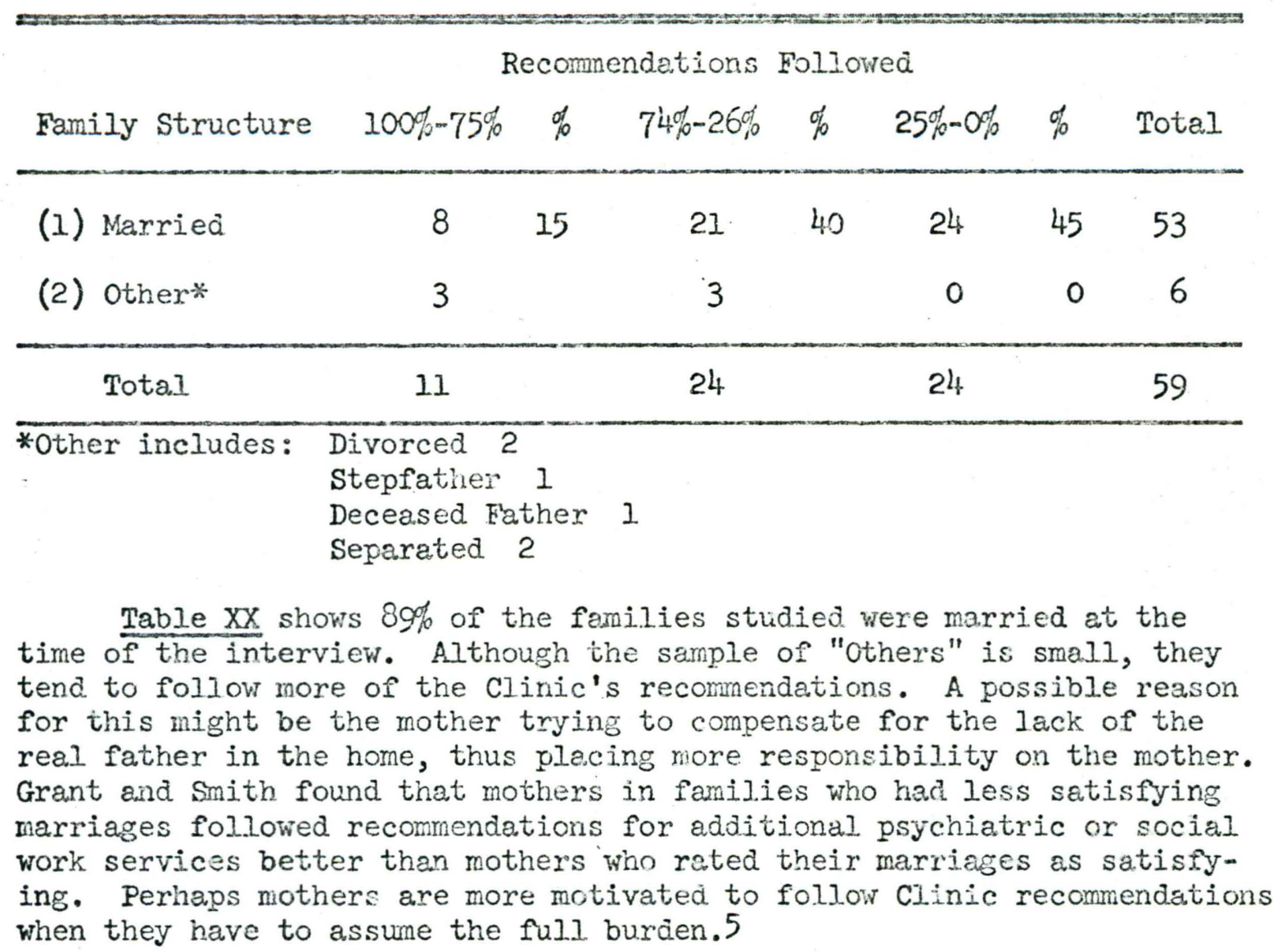

5 op. Cit. 
TABLE XXI

FATHERS AGE VS. FOLIOWING OF RECOMMENDATIONS

\begin{tabular}{ccccc}
\hline & \multicolumn{4}{c}{ Follow Recomriendation } \\
Father's Age & $100 \%-75 \%$ & $74 \%-26 \%$ & $25 \%-0 \%$ & Total \\
\hline $27-39$ & 5 & 8 & 8 & 21 \\
$40-49$ & 1 & 12 & 8 & 21 \\
$50-62$ & 3 & 4 & 8 & 15 \\
\hline Total & 9 & 24 & 24 & $57 *$ \\
\hline$* x^{2}=5.31$ & df $=4$ & $x^{2}$ not significant at $\alpha=.05$ &
\end{tabular}

TABLE XXII

MOTHER'S AGE VS. FOLLOWING OF RECOMRENDATIONS

\begin{tabular}{ccccc}
\hline & \multicolumn{3}{c}{ Follow Recomnendation } \\
Mother's Age & $100 \%-75 \%$ & $74 \%-26 \%$ & $25 \%-0 \%$ & Total \\
\hline $27-39$ & 6 & 11 & 11 & 28 \\
$40-49$ & 3 & 10 & 8 & 21 \\
$50-62$ & 2 & 3 & 5 & 10 \\
\hline Total & 11 & 24 & 24 & 59 \\
\hline$x^{2}=1.14$ & df $=4$ & $x^{2}$ not significant at $\alpha=.05$
\end{tabular}

Tables XXI and XXII show there is no statistically significant relationship between parents age and following through with recommendations. There is a trend toward fathers and mothers in the age range of 27-39 to follow through more consistently than older parents. As would be expected, the fathers ages are slightly older than the mothers ages, with 15 fathers in the age range of 50-62 and only 10 in the same age range for mothers. 
TABLE XXIII

FATHER'S OCCUPATION VS. FOLIOWNAG OF RECOMMENDATIONS

Follow Recommendations

Father's Occupation 100\%-75\% \% 74\%-26\% \% 25\%-0\% \% Total

1) Professional
Managerial

Salesman

2) Craftman

Operatives

$\begin{array}{lllllll}3 & 14 & 11 & 50 & 8 & 36 & 22\end{array}$

3) Private Household

Service Workers

$\begin{array}{lllllll}2 & 12 & 6 & 38 & 8 & 50 & 26\end{array}$

4) Laborer

4. 44

$2 \quad 22$

$3 \quad 339$

$\begin{array}{lllll}3 & 43 & 4 & 57 & 7\end{array}$

Aid

5) Unemployed

Retired

Housewife

Student

$\begin{array}{lllll}2 & 67 & 1 & 33 & 3\end{array}$

6) Deceased and/or
Unknown

$2-300$

2

Total

11

24

24

59

There appears to be a trend in Table XXIII of father's whose occupations are unskilled, retired, or unemployed, not to follow recommenda.tions, as compared to those in the skilled, managerial, and professional occupations. Percentage wise, father's whose occupations are service workers, or private household skijls tend to follow through with recommendations more consistently than those of higher status occupations. This can possibly be accounted for in viewing Farber's study in which he concluded that families of higher status have lower tolerance for de-. viance. Families of higher status place greater importance to assigned roles of family membership in the maintenance of the norms and values. In lower status families, there is greater tendency to emphasize the immediate wants and needs of the family members and less emphasis on status maintenance.

6Bemard Farber, "Eiffects of a Severely Retarded Child on Farnily Integration, "Monograph of the Society for Research in Child Development, 24, No. 2, 1959 and Bernard Farber, Family Organization and Crisis: Maintenance of Integration in Families with a Severely Mentaliy Retarded. Child, "Monograph of the Society for Research in Child Develoument, 25, No. 1, 1960. 
TABLE XXIV

MOTHER'S OCCUPATION VS. FOLTOWING OF RECOMENIATIONS

\section{Follow Recommendations}

Mother's Occupation $300 \%-75 \%$ \% $74 \%-26 \%$ \% $25 \%-0 \%$ \%otal

1) Professional
Managerial

$\begin{array}{lllllll}0 & 0 & 0 & 0 & 2 & 100 & 2\end{array}$

Salesman

2) Craftman

Operatives

$\begin{array}{lllllll}0 & 0 & 1 & 50 & 1 & 50 & 2\end{array}$

3) Private Household

Service Workers

$\begin{array}{lllllll}2 & 14 & 3 & 21 & 9 & 64 & 14\end{array}$

4) Laborers

0

01100

$0 \quad 01$

Aid

5) Unemployed

Retired

Housewife

Student

[ota].

11

22

19

24

4

\begin{tabular}{ll}
$12 \quad 30 \quad 40$ \\
\hline 24 & 59
\end{tabular}

Table XXIV indicates that most of the mothers in the studied families are in the housewife category. There seems to be a trend toward the unemployed mothers following through with more of the Clinic's reconmendations in comparison to working mothers, although it is not statistical. Note that the two mothers in the professional category did not follow through with even 0 to $25 \%$ of the clinic's recommendations. 
TABIE XXV

INCOME VS. FOLLOUING OF RECCMMNDATIONS

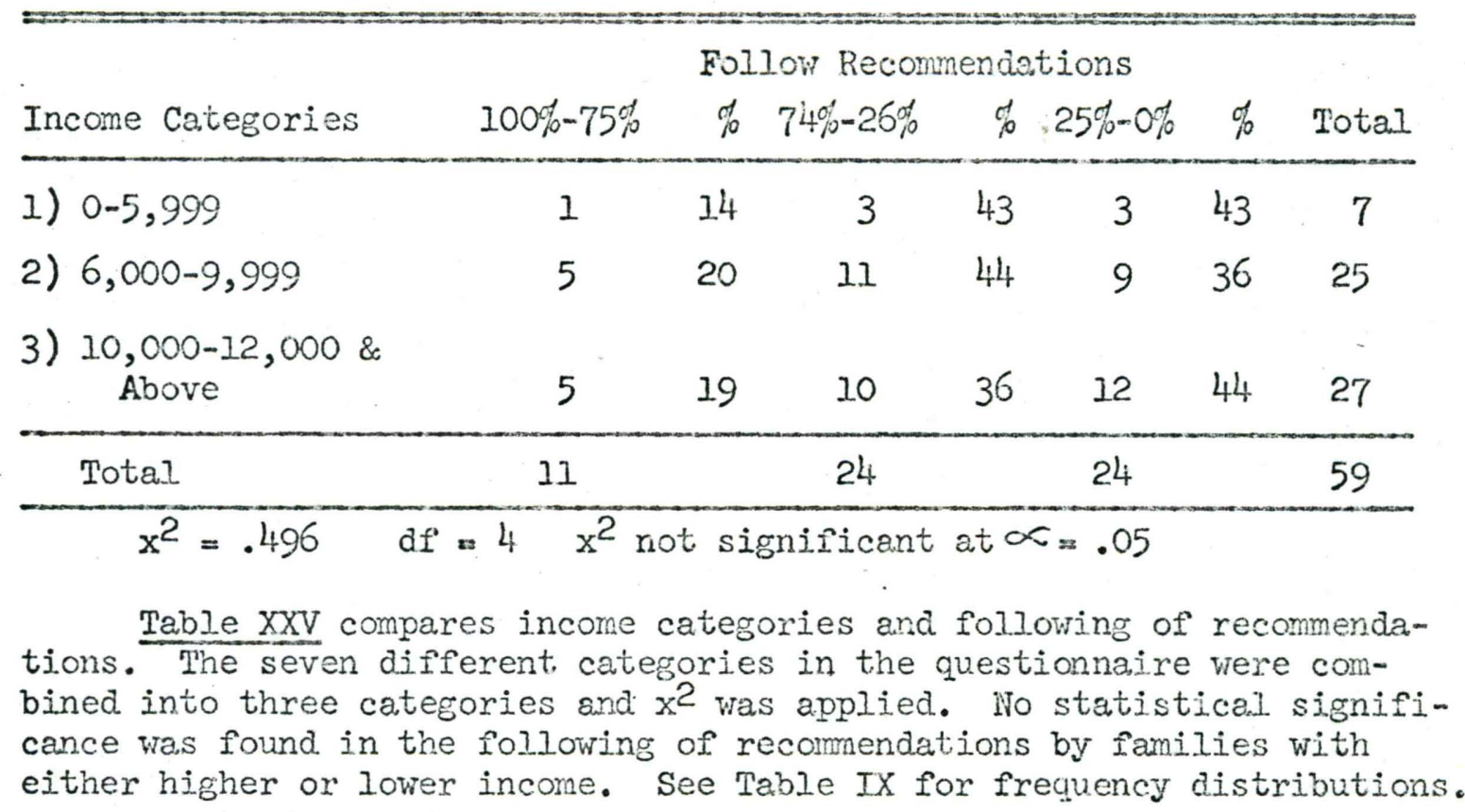

TABIE XXVI

HOME OWNERSHIP VS. FOILOWING RECOMMENDATIONS

\begin{tabular}{lcccccccc}
\hline & \multicolumn{7}{c}{ Follow Recormendations } & \\
Home & $100 \%-75 \%$ & $\%$ & $74 \%-26 \%$ & $\%$ & $25 \%-0 \%$ & $\%$ & Total & $\%$ \\
\hline 1) Renting & 1 & 14 & 3 & 43 & 3 & 43 & 7 & 12 \\
2) Purchasing & 6 & 17 & 13 & 36 & 17 & 47 & 36 & 61 \\
3) Own & 4 & 25 & 8 & 50 & 4 & 25 & 16 & 27 \\
\hline Total & 11 & & 24 & & 24 & & 59 \\
\hline
\end{tabular}

Eighty-eight percent of the families studied either owned their homes or were in the process of purchasing one. Twenty-seven percent of the families had paid up mortgages. This seems to be a rather high percentage but does go along in conjuction with Table IX and high income. There appears to be a trend of those who ow their homes tended to follow recommendations more consistently than those renting or purchasing. 
TABIE XXVII

EDUCATIOR VS. FOLIOWING OF RECONENDATIONS

\begin{tabular}{|c|c|c|c|c|}
\hline \multirow[b]{2}{*}{ Father's Education } & \multicolumn{3}{|c|}{ Follow Recomendations } & \multirow[b]{2}{*}{ Total } \\
\hline & $100 \%-75 \%$ & $74 \%-26 \%$ & $25 \%-0 \%$ & \\
\hline (I) Under 8th Grade & 0 & 3 & 5 & 8 \\
\hline $\begin{array}{l}\text { (2) H.S. Completed } \\
\text { Grades 9-1.2 }\end{array}$ & 6 & 10 & 9 & 25 \\
\hline $\begin{array}{l}\text { (3) College Graduates } \\
13-16\end{array}$ & & & & \\
\hline (4) Over 16 & 4 & 11 & 10 & 25 \\
\hline (5) Unknown & 1 & 0 & 0 & 1 \\
\hline Total & 11 & 24 & 24 & 59 \\
\hline
\end{tabular}

Follow Recommendations

Mother's Education $\quad 100 \%-75 \% \quad 74 \%$ - $26 \% \quad 25 \%$ - $0 \%$ Total

(1) Under 8th Grade $\quad 0 \quad 256$

(2) H.S. Completed Grades $9 m 12$

8

15

14

37

(3) College Graduates

$13-16$

(4) over 16

3

$\begin{array}{rrr}7 & 6 & 16 \\ 24 & 24 & 59\end{array}$

Total

11

$x^{2}=2.521 \quad d f=4 \quad x^{2}$ not significart at $\alpha=.05$

With regard to father's education and the following of recomendations Table XXVII shows there is no statistical significance. The same is true in regard to the mother's education and the following of recommendations as seen in Table XXVII. In the statistical anaiysis of the data, categories 3 and 4 (college education) were combined and the "Unknown" category was not included in the analysis. There does seem to be a trend of both parents with below $8 \mathrm{in}$ grade education of not following recommendations. Also $50 \%$ of the fathers with over 16 years of education did not follow recormendations as consistent as high school or college graduates. This same tendency holds true with regard to the mother's education. One of the explanations for this phenomenon might be that parents with higher education appeared to be more sophisticated and had already researched most of the resources in the area of mental retardation. On the other hand, for parents with lower education, following recommendations for their retarded child night not have been a top priority problem nor may it have presented the stigma to the family. 
TABLE XXVIII

SOURCE OF REFERRAL VS. FOLLOWING OF RECOMMENDATIONS

\begin{tabular}{|c|c|c|c|c|c|c|c|c|c|c|c|}
\hline \multicolumn{2}{|l|}{ Source of Referral } & $\%$ & $\begin{array}{l}50110 \mathrm{w} \\
100 \%-75 \%\end{array}$ & Re & $\%$ & $\begin{array}{l}\text { e n d a t } \\
74 \%-26 \%\end{array}$ & o $\mathrm{n}$ & $\%$ & $25 \%-0 \%$ & $\%$ & Total \\
\hline (1) Physician & & 36 & 4 & 18 & $2]$ & 5 & 23 & 54 & 13 & 59 & 22 \\
\hline (2) School & & 13 & 2 & 12 & 29 & 7 & 43 & 29 & 7 & 43 & 16 \\
\hline (3) Friends & & 9 & 1 & 12 & 25 & 6 & 75 & 4 & $I$ & 12 & 8 \\
\hline $\begin{array}{l}\text { (4) Other } \\
\text { Self-Ref. } \\
\text { Soc. Agency } \\
\text { Spec.Clinic }\end{array}$ & $\begin{array}{l}5 \\
2 \\
5\end{array}$ & 36 & 4 & 30 & 25 & 6 & 46 & 13 & 3 & 23 & 13. \\
\hline Total. & & & 11 & & & 24 & & & 24 & & 59 \\
\hline
\end{tabular}

Table XXVIII shows the relationship between source of referrals and the following of recommendations. The category of "Others" includes 6 self-referrals, 2 social service agencies, and 5 specialist clinic referrals. There appears to be a tendency for those in the "Others" category to follow the recommendations more consistently than those referred by physicians or schools. This could be because the families in the "Others" category were more notivated as they had initiated some action or were involved in seeking some kind of help on their own. More patients were referred by physicians, followed by school referrals. Fifty percent of the physicians referrals followed only $0-25 \%$ of the recomendations made. 
TABLE XXIY

USEABILITY OF CLINIC RECOMMENDATIONS VS. FOLTOWING RECOMMENDATIONS

\begin{tabular}{llllllllll} 
& \multicolumn{7}{c}{ Follow Recommendations } \\
& $100-75 \%$ & $\%$ & $74-26 \%$ & $\%$ & $25-0 \%$ & $\%$ & Total & $\%$ \\
\hline (1) Yes & 8 & 17 & 22 & 48 & 16 & 35 & 46 & 78 \\
(2) No & 3 & 23 & 2 & 15 & 8 & 61 & 13 & 22 \\
\hline Total & 11 & 24 & 24 & 59 \\
\hline
\end{tabular}

In Table XXIX, seventy-eight percent of the families in the study stated they were able to use the clinic's recommendations. It is interesting to note that although this high percentage stated they were able to use the recomendation, thirty five percent of them followed. through with only 0-25\% of recommendations offered. Perhaps this could be a lack of motivation on the part of the parents. Three families stated they were not able to use the clinic's recommendation but were able to follow through with $75 \%$ or more of the ones given. This could be a misinterpretation of the question - meaning able to follow through with all recommendations. Sone of the reasons given for not being able to make use of clinic recommendations were lack of roney, unable to place child in suggested school, unwillingness on the part of the parent to put child in recommended placement, and inability to recall or understand Clinic's recommendations. 
TABLE XXX

PRESENTATION OF RECONAENDATTONS VS. FOLIOWIIG RECOMENDATIONS

2

Follow Recomendations

Could Recomm. Have Been

Presented in a Better

Way?

\% 100-75\% \% क 74-26\% \% क 25-0\% \% Total

$\begin{array}{lllllllllll}\text { (1) Yes - Dissatisfied } & 10 & 1 & 10 & 17 & 4 & 37 & 25 & 6 & 54 & 11\end{array}$

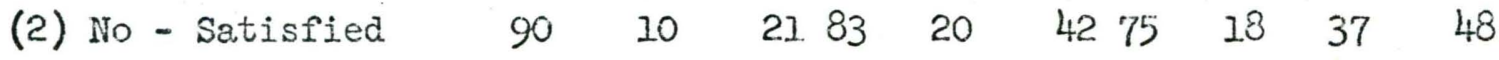

Total.

11

24

24

59

Table XXX compares the way recommendations were presented and the following of recommendations. This table shows that 48 families were satisfied with the way recommendations were presented. It a.Iso shows that those who were satisfied tended to follow more recommendations.

Some of the suggestions dissatisfied parents made were:

a) Seven parents said that more clarified permanent reports were necessary.

b) Two asked for more information with regard to resources in the cormunity and follow-up appointments.

c) One complained about the staff's approach as needing to be changed. 
TABLE XXXI

AREAS WHICH CLINIC WAS HETPFUL VS. FOLLOWING RECOMMENDATIONS

A. Medical Questions Vs. Following Recommendations

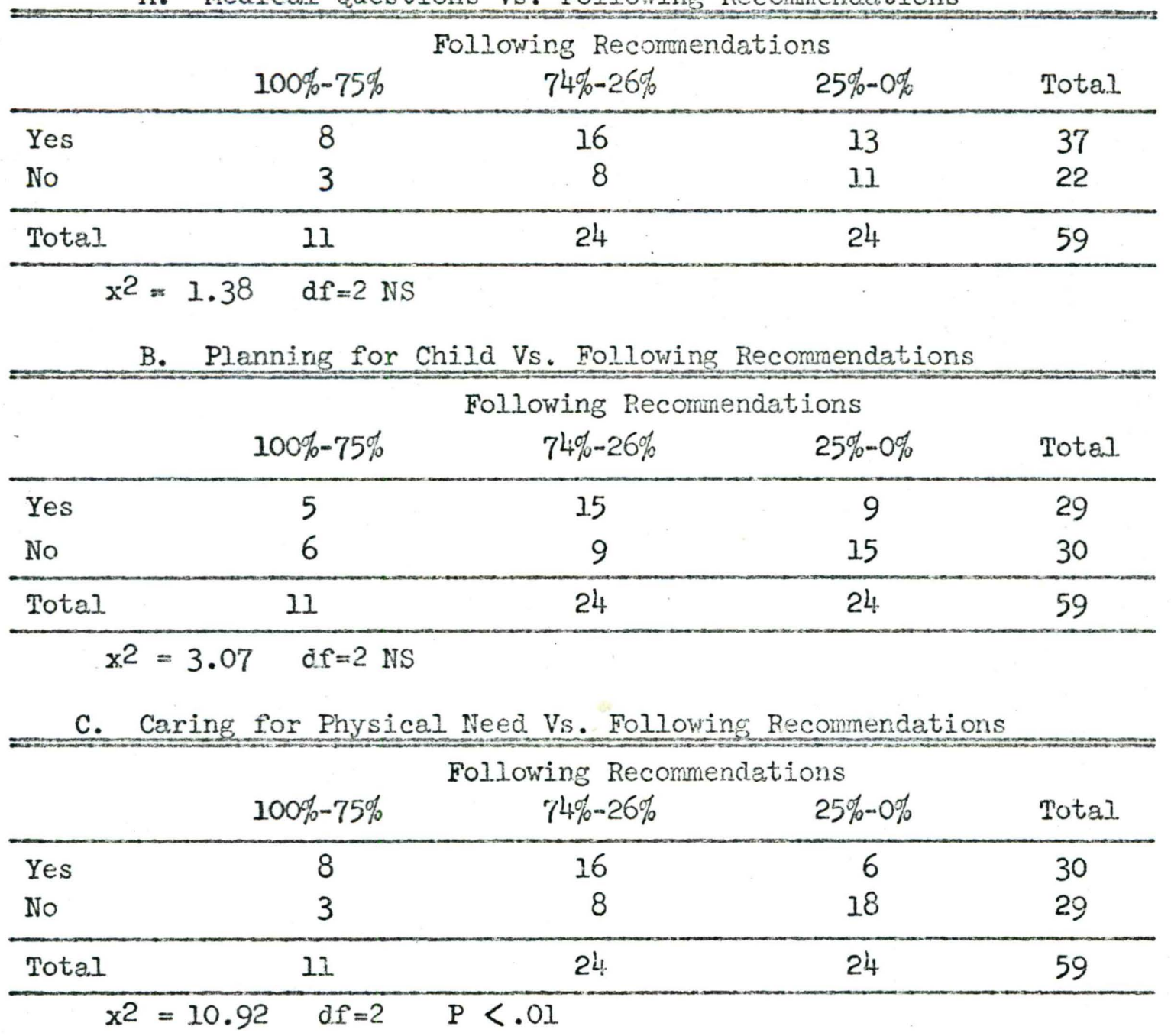

D. Caring for Emotional Needs Vs. Following Recommendations

\begin{tabular}{|c|c|c|c|c|}
\hline & \multicolumn{4}{|c|}{ Following Recommendations } \\
\hline & $100 \%-75 \%$ & $74 \%-26 \%$ & $25 \%-0 \%$ & Total \\
\hline Yes & 8 & 12 & 9 & 29 \\
\hline No & 3 & 12 & 3.5 & 30 \\
\hline Tota.1. & 11 & 24 & 24 & 59 \\
\hline
\end{tabular}


TABLE XXXI - Continued

E. Other Vs. Following Recommendations

\begin{tabular}{lcccc} 
& & Following Recommendations & \\
& $100 \%-75 \%$ & $74 \%-26 \%$ & $25 \%-0 \%$ & Total \\
\hline Yes & 2 & 2 & 5 & 9 \\
No & 9 & 22 & 19 & 50 \\
\hline Total & 11 & 24 & 24 & 59 \\
\hline
\end{tabular}

Table XXXI shows there vas no statistical significance between the Clinic's helpfulness in the areas of medical questions, future planning, emotional needs and the following of recommendations. There does seem. to be a trend toward not following the recommendations in areas where the parents felt the Clinic had not been helpful. In the area of caring for physical needs and the following of Clinic recommendations a statistical significance of $P<. O I$ is seen. This could happen just by chance. The category which seems to be of most help to the parents was helping to understand the medical questions. The category of "others" allowed parents to relate their individual opinions on where they felt the Clinic had helped them. This category was not included in the statistical analysis. Some of the responses to this category were: helped parents to better understand their child's problem, specific help by Clinic in speech, dental care, and school placements. 
TABLE XXXII

\section{DISSATISFACIION OF CLINIC'S PROGRAM BY PARENTS \\ VS. FOLLOWING RECOMMENDATIONS}

Aspects of Clinic's Program Parents Disliked

Follow Recommendations

A. Way they were treated by staff 100-75\% \% 74-26\% \% 25-0\% \% Total
1) Yes
2) No
0

000

1:i

0000
$11 \quad 19 \quad 24 \quad$ i: $24 \quad 41 \quad 59$

B. Way child was treated
1) Yes
2) No
$\begin{array}{rrrrrrr}0 & 0 & 1 & 100 & 0 & 0 & 1 \\ 11 & 19 & 23 & 39 & 24 & 41 & 58 \\ & & & & & & 59\end{array}$

C. Quality of care child received
1) Yes
2) No

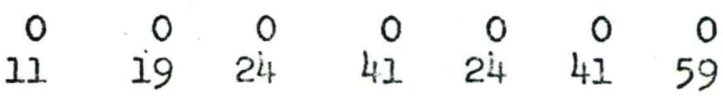

D. Scheduling of sessions
1) Yes
2) No
$\begin{array}{rrrrrrr}0 & 0 & 1 & 50 & 1 & 50 & 2 \\ 11 . & 19 & 23 & 39 & 23 & 39 & \frac{57}{59}\end{array}$

E. Others:

1. Clinic lacks understanding of child...5

2. Inappropriate or wrong diagnosis.. 5

3. Clinic needs further follow-up care \& clarification.......?

4. Personal complaints no coffee - transportation difficulties...2

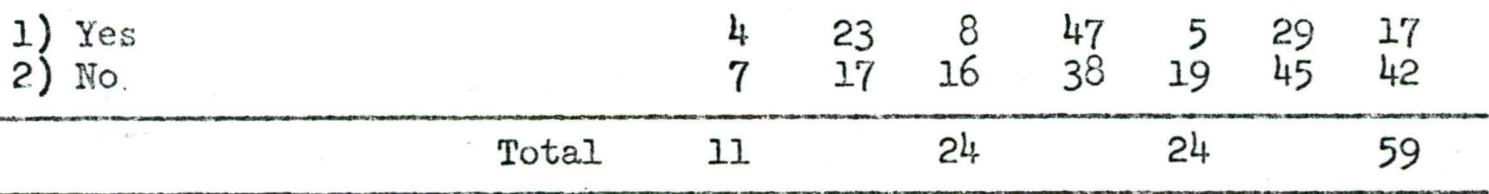

Table XXXII indicates that most of the families studied were satisfied with the Clinic's program in regard to how the staff treated the family, as well as the care and consideration given to both family and child. There were a few areas which some of the families felt the clinic could be improved. These included better understanding of the child by the Clinic, more appropriate diagnosis, need for follow wup care and clearer interpretation of the problem. This, in itself, did not have any statistical significance whether recomendations were or were not followed. 
TABSE XXXIII

DEGREE CLINIC HHJPED PARENTS TO UNDERSTAND CHJLD

VS. FOIIONING OF RECOMNENDATIONS

Follow Recommendations

Degree that Clinic Helped

Parents to Understand Child 100\%-75\% 74\%-26\% 25\%-0\% rotal

\begin{tabular}{llrrr}
\hline (1) Much & 9 & 12 & 17 & 38 \\
(2) Some & 0 & 8 & 4 & 12 \\
(3) Little & 2 & 4 & 3 & 10 \\
\hline Total & 11 & 24 & 24 & 59 \\
\hline
\end{tabular}

$x^{2}=6.05$ df $=4 \quad x^{2}$ not significant at $\alpha=.05$

In Table XXXIII the degree to which the Clinic helped parents to understand their child.--on a scale from "Much" to "Littie".- there was no statistical significance between the parents perception of the degree they were helped vs. the following of recomendations. of 38 parents who indicated that the Clinic helped them much, 17 of these same parents did not follow any recommendations. This may have been due to parents disagreeing with the diagnosis or not finding resources available to follow recommendations. Of those who indicated that they were not helped, they complained that the diagnosis was either wrong or unspecific; they did not understand the Clinic; or the program offered no help or alternatjves for help. 
TABLE XXXIV

CHANGES IN CHILD AND FAMILY LIFE VS. FOLIOWING RECOMMENDATIONS

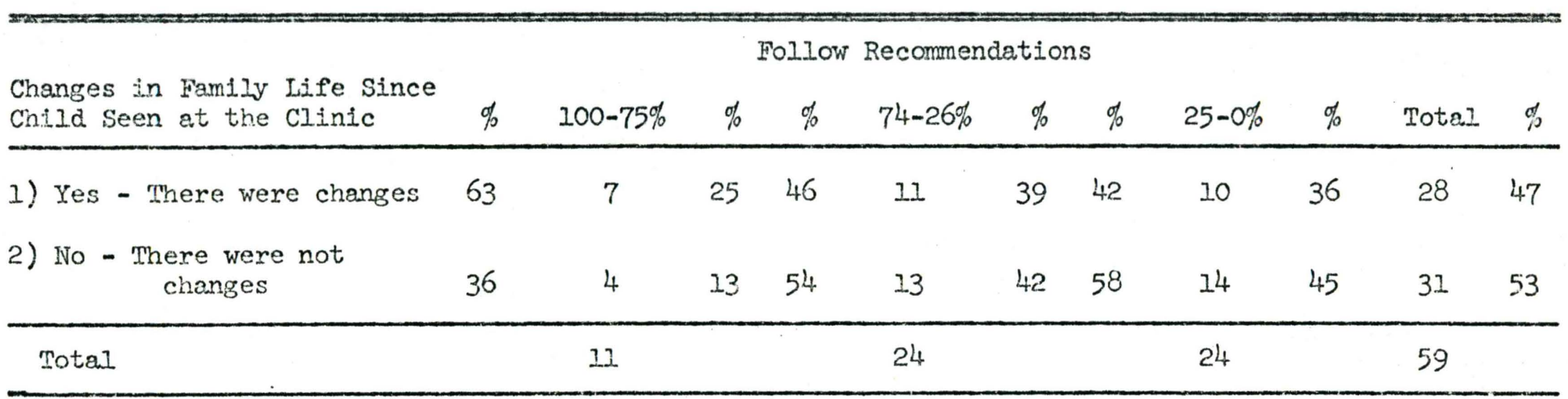

$x^{2}=1.50$ df $=2$ $x^{2}$ not significant at $\alpha=.05$

In Table XXXIV, there was no statistically sjgnificant correlation between changes in family iife since the child was seen at the Clinic and following recommendations of the Clinic. There were 28 families who felt their family life had changed since they have been to the Clinic. Some of the changes the family experienced were in the areas of 1) family understanding of the patient's enotional and physical probiems, 2) better acceptance of the child with his limitations, 3) an awareness of the child's needs such as speech therapy, special schools, and medication. Of those parents who followed $75-100 \%$ of the Clinic's recommendations, $63.6 \%$ indicated that there were changes in family life since the Clinic had seen them. 
STUDY QUESTIONS

I. Is higher income correlated with the following of recommendations?

II. Is the I.Q. of the patient related to the following of Clinic recommendations?

III. Is the level of parental education affecting the following of clinic recommendations?

I. From the data gathered it was determined that there is no statistical significance between higher income and the following of recommendations. This appears to be so even though $50 \%$ of the families have in. comes of $\$ 10,000.00$ or more. Although $27 \%$ owned their homes, there again is no statistical significance to home ownership and the following of recomendations. However, there appears to be a trend indicating that individuals from the unskilled and professional levels follow recomendations less than those individuals who fall in the midole employment brackets -.. skilled or managerial positions.

Most of the patients' mothers are housewives. The data seems to indicate that families having housewives as mothers tend to follow recommendations more than families with working mothers. The study shows that two of the professional mothers did not follow even $25 \%$ of the recommendations. (Refer to Farber's study -- Table XXIV)

II. Results of the survey of the families indicates that if the parents' level of education was at either extreme of the educational continuum the families did not follow through on recommendations. This tendency is supported by occupational trend. (Refer to Tables XXIII and XXIV) 
III. The data shows that there is no statistical significance between I.Q. and the following of Clinic recomendations. Even though there was a small number of pationts in the severely retarded category or lower, there appears to be a trend indicating that this group of parents do not follow through on recommendations. The majority of the patients who went through the Clinic are moderately retarded (36-58). 


\section{HYFCTHESES}

\section{Relationship of Following Clinic Recommendations} to the Income of the Parents
$\mathrm{H}_{\mathrm{I}}$ : There is a difference between income categories (above, bolow, median) and the following of clinic recommenda- tions.

To test this hypothesis, income was defined as the total approximate incone from a.ll sources. The seven incone categories of the guestionnaire were combined into three following: a) 0-5,999 per year; b) 6,000-9,999 per ycar; c) 10,000--12,000 and above per year. A three by three table was set up with income categories by following of recommendations. The results show no significant difference between income categories and following of recomendations. Therefore, the null hypothesis is accepted.

TABLE XXXV

REIATIONSHIP OF FOLIOWING CIINIC RECOMENDATIONS TO THE INCOME OE THE PARENTS

\begin{tabular}{|c|c|c|c|c|}
\hline \multirow[b]{2}{*}{ Income Categories } & \multicolumn{4}{|c|}{ Folliow Recommendations } \\
\hline & $100 \% 75 \%$ & $74 \%-26 \%$ & $25 \%-0 \%$ & Total \\
\hline $0-5,999$ & 1 & 3 & 3 & 7 \\
\hline $6,000=9,999$ & 5 & 11 & 9 & 25 \\
\hline $\begin{array}{l}10,000-12,000 \\
\text { and above }\end{array}$ & 5 & 10 & 12 & 27 \\
\hline Total & 31 & 24 & 24 & 59 \\
\hline
\end{tabular}


Relationship of Following of Clinic Recommendations to the Father's and Mother's Education

$\mathrm{H}_{2}$ : There is a difference between educational levels of fathers and mothers and the following of Clinic recommendations.

To test this hypothesis, the following categories with regard to parents' education were established. 1) Under 8th grade; 2) H.S. completed, grades 9-12; 3) College graduates, 13-16; 4) Over 16; 5) Unknown. Categories (3) and (4) were combined together in the analysis of the data and category (5) was not included in the analysis. A chi square test was used to test whether the parents' education was affecting the following of recommendations. The results as seen in Table XXXVI A and XXXVI B show that (2) with regard to father's education and with regard to mother's education that neither of these is significant at the $\quad .05$ level of significance. Therefore, the null hypothesis can be accepted.

TABIE XXXVI A

REIATIONSHIP OF FOLIOWING OF CLINIC RECONMENDATIONS TO THE FATHER'S AND MOTHER'S EDUCATION

\begin{tabular}{lcccc} 
& \multicolumn{4}{c}{ Follow Recomendations } \\
Father's Education & $100 \%-75 \%$ & $74 \%-25 \%$ & $25 \%$-0\% & Total \\
\hline Under 8th Grade & 0 & 3 & 5 & 8 \\
H.S. Completed & 6 & 10 & 9 & 25 \\
Grades 9-12 & 4 & 11 & 10 & 25 \\
College Graduates & 1 & 0 & 0 & 1 \\
$\begin{array}{l}13-15 \text { \& Above } \\
\text { Unknow* }\end{array}$ & 11 & 24 & 24 & 59 \\
\hline Total & & & & \\
\hline
\end{tabular}

* Not included in the analys is

$$
x^{2}=3.1 .96 \quad d f=4 \quad x^{2} \text { not significant at } \alpha=.05
$$


TABLE XXXVI B

REIATIONSHIP OF FOILONING OF CLINIC RECOMEADATIONS

TO THE FATHER'S AND MOTHER'S EDUCAIION

\begin{tabular}{lcccc} 
& \multicolumn{3}{c}{ Follow Recomendations } \\
Mother's Education & $100 \%-75 \%$ & $74 \%-26 \%$ & $25 \%-0 \%$ & Total \\
\hline $\begin{array}{l}\text { Under 8th Grade } \\
\text { H.S. Completed } \\
\text { Grades 9-12 }\end{array}$ & 0 & 2 & 4 & 6 \\
$\begin{array}{l}\text { College Graduate } \\
\text { 13 16 \& Above }\end{array}$ & 8 & 15 & 14 & 37 \\
\hline Total & 3 & 7 & 6 & 16 \\
\hline$x^{2}=2.521$ & af $=4$ & $x^{2}$ not significant at $\alpha=.05$ & 59 \\
\hline
\end{tabular}


Relationship of Following Clinic Recommendations to the I.Q. of the Patients

$\mathrm{H}_{3}$ : There is a difference in the level of $I . Q$. of the child and the following of Clinic recommendetions.

To test this hypothesis, recommendations were defined as those recommendations given by the staff of the UOMS-CCD to the parents of the retardates. A three by three contingency table (see Table XIX) was constructed with three categories of the following: 100-75\%, 74-26\%, or 25-0\% of the recommendations, by six I.Q. categories, combined into three (see Table II) for frequency distributions. The results show that $x^{2} \quad 6.515$ was not significant at the .05 level. Thus, the nuIl hypothesis was accepted and the research hypothesis rejected.

TABLE XXXVII

REIATIONSHIP OF FOILOWING CLINIC RECOMENDATIONS TO THE I.Q. OF THE PATIENTS

\begin{tabular}{|c|c|c|c|c|c|}
\hline \multirow{2}{*}{\multicolumn{2}{|c|}{ I.Q. }} & \multicolumn{3}{|c|}{ Follow Recormendations } & \multirow[b]{2}{*}{ Total } \\
\hline & & $100-75 \%$ & $74-26 \%$ & $25-0 \%$ & \\
\hline $1-2$ & $\begin{array}{l}\text { Profound \& Severe } \\
20-35\end{array}$ & 0 & 4 & 2 & 6 \\
\hline 3 & $\begin{array}{l}\text { Moderate } \\
36-52\end{array}$ & 4 & 12 & 8 & 24 \\
\hline $4-5-$ & $\begin{array}{l}\text { Mild-Borderline } \\
\text { \& Above } 83\end{array}$ & 7 & 6 & 13 & 26 \\
\hline Tota. & & 11 & 22 & 23 & 56 \\
\hline
\end{tabular}


Other Findings

A finding of significant interest in the study is the fact that the majority of farnilies whose children were evaluated at the UOMS-CCD were satisfied with the way in which the recomnendations were presented to then. Those who were satisfied with the way in which recomendations were presented by staff. also tended to follow through on them. Those families who felt that the recommendations could have been presented in a better or more helpful manner did not tend to follow through on them. These are findings indicated in T'able XXX.

Table XXXII indicates that most of the families whose children were evaluated at the Clinic were satisfied with the way in which they were treated by the staff. It shows that most families were satisfied with the care and consideration given both the child and the family. Although this is a finding of the study, it vas not statistically significant for the following of recommendations by the familites.

Table XXXIV indicates another significant finding of the study which did not seer to have statistical significance for the following of Clinic recommendations. This table reveals that $47 \%$ of the families in the study felt that there have been changes within their family life following their child's evaluation at the UOMS-CCD. Also, on a scale of "Much to None" in Table XXXIII, over half of the study families indicated that the Clinic helped them "much". Again, this does not have statistical significance for the following of recomendations by those families.

other significant findings of the study related to the source of referral to the UOMS-CCD. Physicians comprised the largest single 
referral source. Table XI indicates that among fexales referred, an equal number were referred by physicians and schools. However, among males referred, the largest referral source was physicians. The study also reveals that as children reach edolescence, the school as well as the physician becomes a significant referral. source to the clinic. An additional finding of the study is that only $29 \%$ of the families continue to consult the clinic for relatea problems; most femilies return to their physician for related problems.

In regard to the distribution of retarded children in the populaw tion according to the census tract, this sample did not show a significantly high concentration of retarded children from any particular location or socio-economic group in the Portland area. 
CHAYTER IV

SUMMARY AND IMPLICATIONS

The first section of this chapter deals with the sumary of the study, followed by the implications resulting.

Purpose: The purpose of this study was to determine how effective the UOMS-CCD was from the standpoint of the users of the services. One criterion upon which to base a judgment of effectiveness of the clinic was to see if the studied fanilies were able to follow the recomendations suggested by the clinic.

Sarnple: A random sample of 100 coses was selected from the 232 patients who hed been through the Clinic prior to January, 1968. This sample was geographically restricted to children whose parents had a Portland address. Out of the 100 sample selected, 59 were available for interviewing. The others could not be located, moved from the city or rerused the interview.

Fypotheses: The following three research hypotheses were posed for testing.

(1) There is a difference between income categories (above, below, medien) and the pollowing of clinic recommendations.

(2) There is a difference between educational levels of fathers and mothers and the following of Clinic recommendations.

(3) There is a difference in the level of I.Q. of the patient and the following of Ginic recomendations.

The $x^{2}$ was used in testing the hypotheses and the findings resulted in no 
statistical difference between the three variables and the criteria of following recomendations. Therefore, the null hypotheses were accepted. Although these were not statistically significant, some trends were indicated. In regard to education and the following of recommendations, it is noted that parents of both the lower and high education continuum tend not to follow recommendations as consistently as those of average education. There was a trend indicated in regard. to I.Q. and following recommendations in that most parents whose children fell within the moderate range of ability, follow recommendations more consistently than others.

Other findings revealed that the majority of the study population were satisfied with the treatment they received from the Clinic. Also, most were satisfied with the way the recommendations were presented. Forty-seven percent felt there had been changes in their family life since being seen at the clinic.

Physicians were the largest single referral source to the Clinic and most families continued to consult the physician for related problems while only $29 \%$ of the families continued to consult the clinic. The number of blacks seen at the Clinic was in proportion to the population of the Portland area. 


\section{Implications of the Study}

Some significant implications of this study relate to the ability of the study fomilies to utilize the recomendations of the UOMS-CCD. Table XXIX suggests several implications regarding Clinic recommendations. One important finding is that study families felt that recommendations should have been more clearly defined for their understanding. Table XXIX also indicates that $35 \%$ of the study families said they could use the Clinic's recommendations but then did not do so. It is possible to speculate that additional counseling services may have helped motivate families to follow through on recommendations where resources were available in the community. Another specvlation is that a family's lack of financial resources may have interfered with following the Clinic's recomrnendations. In such cases, perhaps the clinic could make more realistic recommendations in accord with the family's income.

Table XXX describes the families' responses to the way in which recommendations were presented to them. Most families (48) were satisfied with the way recommendations were presented but for those families who were dissatisfied, seven said that clearer, written evaluations were necessary; two said that more information and encouragernent to follow through on available resources was necessary, and only one felt that the approach of the professional staff should be changed.

Table XXXII describes aspects of the Clinic's program which the study familjes disliked. It should be noted, first, that the general reaction of study farnilies to the services provided by the Clinic was one of satisfaction. Among those who expressed some dissatisfaction, five families felt that the clinic did not individualize each child 
enough. An additional five families expressed dissatisfaction with the nature of the diagnosis of their child received; they later found it to be unsubstantiated. Significantly, seven families again stated that they required a clearer interpretation of the child's problems and also felt that more follow-up contact by the Clinic would have been helpful. Further implications of the study are suggested by Descriptive Table XXXI. An open-ended question designed to discover in which areas the Clinic was most helpful, revealed that study families feit the Clinic was generally helpful in better understanding their child's problems. It also revealed that study families felt the clinic to be very helpful in such specific areas as speech, dental care, school placement, and counseling for behavioral adjustment.

Table XXVIII reveals that those families who were selfwreferred or: referred by social agencies tended to follow through on recommendations more readily than those referred by physicians or schools. The reason for this might be that those self-referred families were more highly motivated and that those referred by social agencies received preparation and follow-up which contributed to following of recomendations. 


\section{BTBLICGRAPIYY}

Barclay, A., Goulet, L.R., Aoltgrewe, M.M. and Sharp, A.R., "Parental Evaluation of Clinical Services for Retarded Children, "American Journal of Mental Deficiency, 67, No. 2, (Sept. 1962), 232-237.

Caldwell, B., Manley, E., and Nisson, Y., "Reactions of Community Agencies and Parents to Services in a Clinic for Retarded Children," American Journal of Mental Deficiency, 65, No. 5, (March, 1961), $582-589$.

Farber, Bernard, "Effects of a Severely Mentally Retarded Child on Family Integration, "Monograph of the Society for Research in Child. Development, 24, No. 2, Serial No. 71, 1959.

Farber, Bernard, "Family Organization and Crisis: Maintenance of Integration in Families with a Severely Mentally Retarded Child," Monograph of the Society for Research in Child Develooment, 25, No. I, 1960.

Graljker, B.V., Parmalee, A.H., and Koch, R., "Attjtude Study of Parents of Mentaljy Retarded Children: II. Initial Reactions and Concerns of Parents to a Diagnosis of Mental Retardation," Pediatrics, 24, (1959), 819-821.

Grant, James, and Smith, Evelyn, "After Diagnosis - What?", Child. Development and Mental Retardation Center, University Hospital, University of Washington (pamphlet).

Justice, Robert Sidney, Copins Pattems of Parents of Mentally Retarded Children, p. 2, June, 1968, Unpublished Doctoral Dissertation, U.S.C.

Justice, R.S., Campbell, M.M., O'Connor, Gail, and Sabotta, Fugene, A Look at the Population Served by a University Clinic for Retarded Children; Mental Retardation (in press).

Koch, R., Graliker, B., Sands, R., and Parmalee, A., "Attitude Study of Parents with Mentally Retarded Cnildren: Evaluation of Parental Satisfaction with the Medical Care of a Retarded Child," Pediatrics, 23, No. 3, (March, 1959), 582-584.

Mcintire, M.S., and Kiekhaeker, T.C., "Parenta? Reactions to a Clinic for the Evaluation of the Mentally Retarded," Nebraska Medical Journal, 48, (1963), 69-73.

Portland, Oregon Industrial Location Facts File, Greater Portland Area, The Portland Chamber of Commerce, Jamuary, 1962.

Ricks, Helen, "A Manual of Terminology and Classifjcation in Mental Retardation," Monograph Suppl. to Americal Journal of Mental Deficiency, (2nci ed., 1961), 59. 
Siegel, Sidney, Nonparametric Statistics for the Behavioral Scierces, McGraw-Hill Book Company, Inc., New York, Toronto, London, 1956.

The Oregon Economy and Outlook, State of Oregon Department of Commerce, Economic Development Division, 5th ed., March, 1968.

The Secretary's Comrnittee on Mental Retardation, Mental Retardation Programs of the U.S. Department of Health, Education, and Welfare, (Washington, U.S. Department of Health, Fducation, and Welfare, Feb., 1962), 11.

U.S. Bureau of the Census, U.S. Census of Population and Housing: 1960; Census Tracts, Final Report P.H.C. (I) - 12l, Portland, U.S.G.P.O., 1962.

"Where to Turn," (parphlet), Tri-County Community Council, Fortiand, Oregon, 1969.

Young and Veldman, Introductory Statistics for the Behavioral Sciences, 423. 
APPENDTX A

RECORD DATA

I. EAMILY

a. Name:

Father

Mother

Mother's Address

Phone

b. Family structure:

Married

Steprather

Deceased Father

Divoreed

Stepmother

Deceased Mother

c. Rece:

White

Black

other

d. Religion:

Protestant

Church

Catholic

Jewish

other

II. PATIETI

a. Name:

Age:

b. Sex:

Male

Female

c. I.Q.: Profound

Severe

Moderate

Mild

Borderline

Less than 20

$20-35$

$36-52$

$53-68$

$69-83$

d. Date of Evaluation: 
e. Source of Referral: Physician.

$$
\text { School }
$$

Friend

Family

other

f. Speciric Medical Diagnosis: (List from Medical Report)

g. Recommendations: (Check)

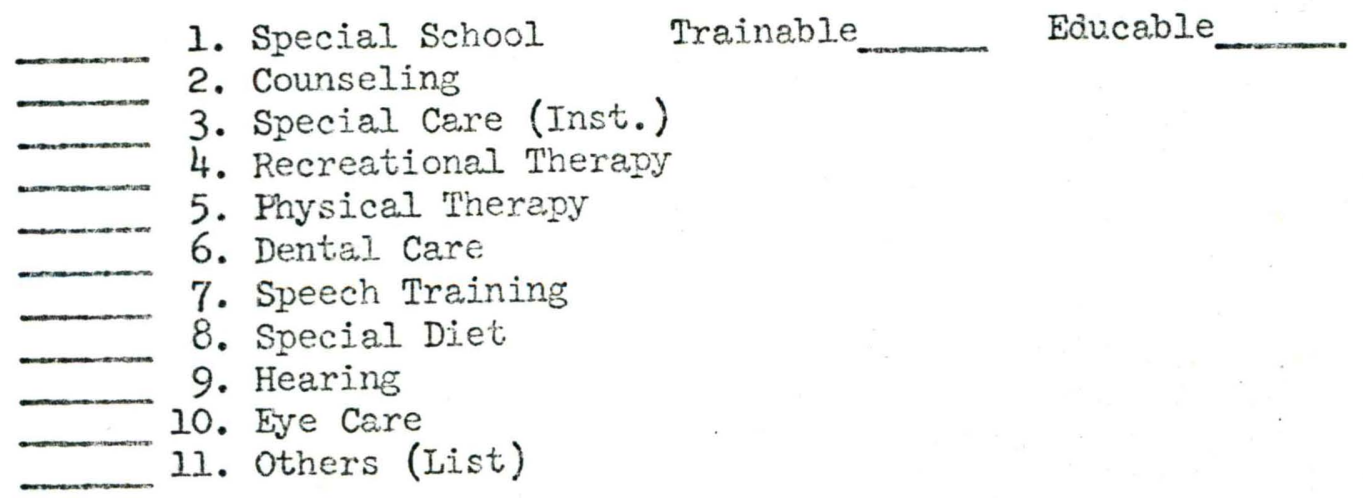




\section{SEMI-STRUCTURED INTERVIEN WITH MOTHER}

I am a graduate student at the School of Social Work involved in a research project with the Crippled Children's Clinic to determine how effective and helpful the clinic is. Yov could be helpful by answering some questions for us. We are interested in knowing how useful the Clinic was in regard to your family. All of the information is confidential and names will not be used in the project.

I. First I would like to check our information regarding family background.

A. Age: Father

Children

Mother

B. Highest grade completed:

Father

Never Attended: Father

Mother Mother

C. Occupation: Fy,ther \# Mother \#.

1. Professional, technical and kindred workers

2. Manager, officials and proprietors, except farm

3. Sales workers

4. Craftsman, foremen and kindred workers

5. Operatives and kindred workers

6. Private household workers

7. Service workers, except private household

8. Farm owners, managers, foremen and laborers

9. Laborers, except farm and mine

10. Iiving on aid.

11. Unemployed (not retired, includes housewives head of household, not employed and not on aid)

12. Retired (no prior occupation given)

13. Housewife (not head of household and not working) 
D. Total approximate income of family from all sources: \#

1. Under $\$ 2,000$

2. $2,000-3,999$

3. $4,000-5,999$

4. $6,000-7,999$

5. $8,000-9,999$

6. $10,000-11,999$

7. 12,000 and over

E. Home

Renting

Purchasing

Own

other

II. How did you hear about the Clinic?
A. Physician
C. Friends
B. School.
D. Other

III. Who reierred you to the clinic?
A. Physician
c. Friends
B. School
D. other

IV. In which of these areas was the Clinic heloful to you?

A. Understanding medical questions about your child

B. Planning for your child's future

C. Caring for your child's physical needs

D. Caring for your child's emotional needs

E. Other

v. Was there any aspect of the Clinic's program you dian't like?

A. Way you were treated by staff?

B. Way your child was treated by staff?

C. Quality of care your child received?

D. Scheduling of the Clinic sessions?

E. other?

VI. Do you feel the Clinic has better helved you understand your child?
A. Much
c. Little
B. Some
D. None

E. If none, what would have been more helpful? 
VII. Did your family life change after the birth of your child?
A. Much
c. Littie
B. Some
D. None

E. In what way did it change?

VIII. Have there been any changes in your family life since your child has been seen at the Clinic?
A. Yes
In what way?

B. No

IX. Can you tell me what the Clinic's recommendations were?

A. Yes List:

B. No

X. Were you able to use the clinic's recommendations?

A. Yes

B. No

List why not:

XI. Could the recommendations have been presented to you in a better way?
A. Yes List:

B. No

XII. Who do you see now when you have guestions concerning your child?

A. Public Health Nurse

c. Clinic

B. Physician

D. School

E. Other List: 
XIII. Social work inpressions to be filled out following the interview:

A. Quality of the mother-child relationship:
1. Accepting
3. Rigid
2. Rejecting
4. Flexible

B. Mother's self-estem:

I. Excellent

3. Fair

2. Good

4. Poor

c. Mother's attitude toward interview:
1. Cooperative
2. Uncooperative

D. Would you describe mother as any of the following?
1. Hostile
3. Depressed
2. Dependent
4. Aggressive

5. Passive

E. Quality of family relationships:

1. Fixcellent

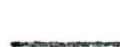

2. Good
3. Fajin

4. Poor 


\section{APPENDIX C}

I. Behavior Symptoms
1. Hyperactive
2. Short Attention Span

II. Miscellaenous Lab Tests
1. Urinalysis
2.
3. Pinworm
4. Densities

III. Miscellaneous Physical Findings

a) Eye 5. Astignatism 10. Hyperopia 21. Esotropia

b) Ear 24. Bilateral Hearing Loss

c) Palate 13. High Arch

d) Nose 19. Epistaxis (nosebleed)

e) Mouth Breather

22-27. Chronic Gingivitis

6. Active Dental Curves

f) Heart 1.4. Pansystolic Murmur

26. Enlarged Cardiac Silhouette

28. Ductus

g) Skull 8. Microcephaly

h) Abdomen

15. Diastasis Recti. (spread of rectus muscles)

i) Bone 11. Bone Retardation

j) Obesity

k) Scoliosis

IV. Syndrome

4. Down's

9. Spastic Dysplegia (cerebral palsy) 
v. Neurological Findings

a) Physical Findings

9. Spastic Dysplegia

16. Abnormal gait

18. Bilateral Clonus

17. Babinski

b) Iab

3. EEG Abnormal

c) Seizure Disorder

d) Behavior a,s I

e) Prysical Findings - Skull, Eye, Ear in III

VI. Speech

12. Echoic

20. Expressive Aphasia 